\title{
Kūdras resursi un to izmantošanas iespējas
}

\author{
Jānis Krūmiṇš ${ }^{1}$, Artis Robalds ${ }^{2}$, Oskars Purmalis ${ }^{3}$, Linda Ansone ${ }^{4}$, Dmitrijs Poršņovs ${ }^{5}$, Māris Kḷaviņš̌ \\ Valdis Seglinsš ${ }^{7},{ }^{1-7}$ University of Latvia
}

\begin{abstract}
Kopsavilkums. Latvijā un pasaulē kūdra tiek izmantota un iegūta daudz mazākā apjomā nekā tas būtu ekonomiski pamatoti, neapdraudot dabas vērtības un to aizsardzībai paredzētās teritorijas. Rakstā novērtēti Latvijas purvi un kūdras resursi, kā arī to izmantošanas jomas. Tiek sniegts ieskats purvu un kūdras klasifikācijā, kūdras veidošanās procesā un to ietekmējošajos faktoros.
\end{abstract}

Atslēgas vārdi: kūdra, kūdras mikrobiālā aktivitāte, kūdras preparāti, tautsaimniecība.

\section{IEVADS}

Purvi ir nozīmīga biosfēras daḷa, bet š̄is komponentes izvietojums pasaulē ir nevienmērīgs. Lielākās platības tie aizņem galvenokārt Eirāzijas kontinenta dal̦ā, kur valda mērena klimata apstākḷi - Krievijā, Somijā, Polijā un Zviedrijā. Purvi pašās lielākajās platībās ir koncentrēti galvenokārt mērenā klimata joslā un polārajos apgabalos, kopumā aizṇemot līdz 3\% planētas sauszemes virsmas [1]. Purvi veidojas kūdras uzkrāšanās rezultātā, apstākḷos, kad nokrišņu daudzums būtiski pārsniedz iztvaikošanas intensitāti. Purvu veidošanās ir ḷoti nozīmīga vielu bioǵeoḳīmiskās aprites cikla sastāvdaḷa un ir iesaistīta oglekḷa, slāpekḷa un citos vielu aprites ciklos [2]. Mūsdienu purvu attīstības sākums izsekojams apmēram 9000 gadu senā pagātnē, tomēr visintensīvākā purvu veidošanās un biezāko kūdras slāṇu uzkrāšanās norisinājusies holocēna klimatiskā optimuma laikā (atlantiskais laiks) pirms apmēram 8000 - 4800 gadiem, kad klimats bija piemērots veǵetācijas attīstībai un turpmākai augu atlieku saglabāšanai pēc atmiršanas.

Pateicoties unikālajām kūdras fizikālajām un ķīmiskajām ipaš̄ībām, pastāv loti plašs šo organogēno nogulumu pielietojuma spektrs. Īpašību kopums ir atkarīgs no kūdras tipa, kuru ir noteikuši kūdras veidošanās apstākḷi un vide. Piemēram, jau gadu tūkstošiem augstā tipa kūdra ir zināma, tās konservējošo īpašību dēḷ, kuru pamatā ir vides skābums, anoksiskie apstākḷi u.c. raksturlielumi. Savukārt zemā kūdra izsenis tiek izmantota augšņu uzlabošanai, pateicoties vērtīgajām minerālvielām tās sastāvā.

Šì apskata mērķis ir pievērst uzmanību kūdras resursu nozīmei tautsaimniecībā un ierosināt š̄i derīgā izrakteņa ieguves apjomu paplašināšanu līdz ekonomiski pamatotiem apjomiem, kas būtu neatsverams ieguldījums valsts ekonomikā.

\section{PURVI UN TO KLASIFIKĀCIJA}

Pēc vienkāršākās definīcijas purvi ir pārmitri zemes virsmas nogabali, kuros pastāvīgos vai ilgstoši periodiskos mitruma apstākḷlos uzkrājies kūdras slānis. Purvam pielīdzināma ir teritorija, kurā kūdras slānis nenosusinātā stāvoklī ir biezāks par $30 \mathrm{~cm}$, bet meliorācijas darbu rezultātā tas saglabājas vismaz $20 \mathrm{~cm}$ biezs [3, 4]. Purvu tipus nosaka to ǵeogrāfiskais novietojums, minerālais pamatslānis, purva ǵenēze, veǵetācijas raksturs, barošanās apstākḷi, hidroloǵiskais režīms, purva attīstības stadija un vairākas citas pazīmes. Atšksirīgo pazīmju un tipizācijas mērķu dēḷ, daudzviet pasaulē pieturas pie atšķirīgām klasifikācijas sistēmām [5]. Visbiežāk par būtiskāko purva pazīmi tomēr atzīst specifisko purva veǵetāciju, kas atkarīga no purva barošanās apstākl̦iem [6], un arī Latvijā purva tipu klasifikāciju galvenokārt nosaka pēc to barošanās veida un veǵetācijas rakstura. Parasti pēc šiem parametriem izškirir 3 purva tipus - zemā tipa, pārejas tipa un augstā tipa purvus. Tomēr purvu klasifikācijai nav iespējams izmantot universālus indikatorus, jo purvi pastāvīgi attīstas un mainās, līdz ar to purva tips norāda tikai uz pašreizējo attīstības fāzi [7]. Savukārt ekologiijā purvu klasifikācija ir nedaudz atšksirīga un atkarībā no barošanās veida, izdala divus purvu tipus - ombrotrofos purvus un mineratrofos purvus [8], ekoloǵiskās klasifikācijas pazīmes vislabāk atspoguḷo purva attīstības dinamiku [9]. Ombrotrofo purvu veǵetācija barības vielas un ūdeni uzṇem tikai no nokrišniem, un no tā izriet, ka ombrotrofie purvi pēc minerālbarošanās tipa atbilst augstajiem purviem. Šādi purvi visbiežāk ir hidroloǵiski un hidroǵeoloǵiski izolēti no apkārtējās vides - starp tiem nenotiek mijiedarbība. Ombrotrofos purvus klasificē pēc skābuma pakāpes, parasti vides $\mathrm{pH}$ reakcija $<4$. Kā klasificēšanas kritēriju var izmantot arī kalcija saturu purva rāvā un ombrotrofajos purvos tas sastāda mazāk par $2 \mathrm{mg} / \mathrm{L}$.

Nokrišņu ūden̦i satur lıti maz barības vielu, tādēl ombrotrofie purvi ir veǵetācijas ziñā vienveidīgi un nabadzīgi, tiem raksturīga epifētiskā veǵetācija [8]. Minerotrofie purvi barības vielas un ūdeni uzņem galvenokārt no pazemes un virszemes ūdeñiem (zemie un pārejas tipa purvi). Minerotrofie purvi parasti tiek izdalīti trīs barības vielu līmeņa grupās, robežas starp šīm grupām ir visai difūzas: oligotrofie purvi (pH 4,5); mezotrofie purvi ( $\mathrm{pH} 5,5)$; eitrofie purvi ( $\mathrm{pH} 5,5$ 7,4) [8]. Pēc veǵetācijas īpatnībām Latvijas purvi pieskaitāmi pie ziemel̦u tipa purviem, kas plaši izplatîti boreālajā zonā.

Purvu izvietojums atkarīgs no reljefa īpatnībām. Augstie purvi veidojušies galvenokārt lēzenu zemieņu ūdensšķirtņu rajonos. Zemākajās līdzenumu vietās, kā arī starppauguru ieplakās veidojas zemie un pārejas tipa purvi [4]. Veidojoties zemā tipa purviem, raksturīgi eitrofi augu barošanās apstākḷi. Purva veǵetācija uzṇem barības vielas galvenokārt no mineralizētiem gruntsūdeņiem vai virszemes ūdenstecēm. Raksturīga zemo purvu iezīme ir ūdens necaurlaidīga pamatne, ko Latvijas apstākl̦os var veidot, piemēram, glacigēnie morēnas nogulumi. Zemā tipa purvi veidojas aizaugot stāvošām ūdenstilpnēm, kā arī ieplakās pārpurvojoties minerālgruntij. Zemo purvu veǵetācijā dominē pārsvarā sūnas un dažādi lakstaugi - grǐšlıi, niedres, kosas utt. [10]. Zāḷ purvos kūdras slāņa biezums ir relatīvi neliels salīdzinājumā ar citu tipu purviem, kā arī vērojama 
paaugstināta dabiskā mitruma (>80\%) un augsta mineralizācijas pakāpe (6 - 16\%). Kūdras sadalīšanās pakāpe ir augsta (20 - 50\% un vairāk), līdz ar to kūdras reakcija parasti ir gandrīz neitrāla un $\mathrm{pH}$ ir aptuveni $6-7$ [4].

\section{Purvu un kūdras veidošanās procesi un tos ietekmējošie faktori}

Purvi veidojas pārpurvojoties sauszemei un aizaugot ūdenstilpēm vai ūdenstecēm, kad paaugstināta mitruma apstākḷos tiek palēnināta augu atlieku sadalīšanās un sākas kūdras uzkrāšanās [11]. Purvu veidošanās procesā liela nozīme ir virsmas topogrāfijai un klimatiskajiem apstākḷiem. Gravās, senlejās, izrobotās morēnu paugurainēs, zemienēs vai viļ̣notos līdzenumos var uzkrāties stāvoši ūdeņi un veidoties purvi. Reljefs pieder pie purvu veidošanās procesu ietekmējošiem komplicētajiem faktoriem [12]. Augstienēs sašaurināta un padziļināta reljefa dēl purviem ir liela vertikāla un maza vai cieši ierobežota horizontāla izplatība, tāpēc augstienēs ir sastopami visdziḷākie purvi, kuru dziḷums svārstās no 9 līdz $10 \mathrm{~m}$, bet tie aizṇem salīdzinoši nelielas platības. Līdzenumos un zemienēs vērojama pretēja parādība te sastop vislielākos purvus platības ziņā, bet ievērojami seklākus, un to vislielākais dzilums svārstās no 6 līdz $8 \mathrm{~m}$. Purva veidošanās sākumposmā lıti svarīga nozīme ir ūdens mazcaurlaidīgajam minerālgrunts slānim. Turpmāko attīstības gaitu nosaka un uztur reljefs un klimatiskie apstākḷi. Piemērots minerālgrunts pamatslānis rada ne vien labvēlīgus priekšnoteikumus purvu veidošanās procesiem, bet arī nosaka purva tipu, kūdras slāņu biezumu un kopējo platību. Ja teritorijas pamatnē ir nabadzīgs substrāts, veidosies sūnu purvi, uz minerālvielām bagāta substrāta savukārt veidosies zāḷu purvi vai atsevišksi to slāņi [14]. Arī klimats ir viens no noteicošajiem purvu veidošanās faktoriem. Augu atlieku sadalī̌sanos un augu masas pieaugumu, tātad arī kūdras uzkrāšanās intensitāti, nosaka nokrišnu, iztvaikošanas un temperatūras režīmu savstarpēja sakarība [15]. Mitrums un temperatūra ir vieni no svarīgākajiem faktoriem kūdras veidošanās procesā. Paaugstināta temperatūra vai mitrums var kavēt kūdras veidošanās procesu. Augsta temperatūra veicina augu atlieku piln̄̄gu mikrobioloǵisko sairšanu, bet pārmērīgs mitruma daudzums kūdras slāņu eroziju [16].

Purva attīstībā izdala trīs pamatstadijas: veidošanās, attīstības un degradācijas. Vairumā gadījumu purva veidošanās sākas ar zemā purva fāzi, kas secīgi pāriet pārejas purva fāzē un noslēdzas ar augsto purvu [17]. Sauszemes pārpurvošanos veicina vēss klimats ar lielu nokrišņu daudzumu, kas pārsniedz iztvaikošanu [10]. Pārpurvošanās faktori ir arī līdzens reljefs ar apgrūtinātu ūdens noteci un barības vielu izskalošanās no augsnes, kas izraisa straujas izmaiņas veǵetācijas augšanas apstākļos [18]. Atšķirības augu ķīmiskajā un strukturālajā sastāvā norāda, ka atsevišksas augu sugas un augu daļas var veidot kūdru, bet citas tajos pat apstākḷos to nevar - ne visi augi var tik iekḷauti kūdras sastāvā [19]. Pats svarīgākais faktors, kas nosaka kūdras uzkrāšanās mehānisma raksturu, ir ūdens, kas samazina skābekḷa pieejamību augiem [20]. Rezultātā relatīvi aukstos un anaerobos apstākḷos aktivizējas sadalīšanās procesu veicinošu mikroorganismu darbība [21]. Lai kūdras slāņi varētu veidoties, mitruma daudzumam ir jābūt noteiktās robežās, kas balansē no nepieciešamā mitruma daudzuma purva augāja attīstībai, no vienas puses, un mitruma daudzuma, pie kura sāk attīstīsies anoksiski apstākḷi, no otras [22].

\section{Latvijas purvi un kūdra, to veidošanās un izplatības likumsakarības}

Latvijas klimatu ietekmē atlantiskās gaisa masas un Baltijas jūras tuvums. Kombinējoties šiem apstākḷiem, raksturīgs augsts atmosfēras mitrums un vidējs temperatūras režīms, kas veido mērenu klimatu. Latviju šksērso aptuveni no 120 līdz 140 cikloniem gadā un raksturīgs nokrišņu pārsvars pār iztvaikošanu. Tendence nokrišņiem pārsniegt iztvaikošanas daudzumu, viegli vil̦nainais reljefs un vāji caurlaidīgie pamatieži Latvijas reljefa ieliecēs un padziļinājumos, rada labvēlīgus apstākḷus purvu attīstībai [23]. Lielākā daļa Latvijas purvu veidojušies reljefa ieliecēs, kas izveidojās apledojuma kušanas ūdencu darbības rezultātā. Izṇēmums gan ir piekrastes zonas, kur reljefs veidojās Baltijas jūras attīstības stadiju gaitā, galvenokārt Baltijas ledus ezera stadijā un Litorīnas jūras stadijā [13]. Senāko Latvijas purvu vecums parasti nepārsniedz desmit tūkstošus gadu. Latvijā kūdras nogulumi vairāk nekā 1 ha platībā un ar kopējo biezumu virs $0,3 \mathrm{~m}$ sedz $10,4 \%$ teritorijas. Purvi izvietojas pa visu Latvijas teritoriju, tomēr to izplatības laukumi ir atkarīgi no dabas reǵioniem, un lielākie Latvijas purvi, īpaši augstā tipa purvi, atrodas Austrumlatvijas zemienē, Piejūras zemienē, Viduslatvijas zemienē un Ziemel̦vidzemes zemienē lielākajās reljefa ieliecēs un piejūras teritorijās. Purviem visbagātākā ir Ziemel̦vidzeme, šeit raksturīga loti liela īpaši augsto purvu izplatība. Augstie purvi aizṇem plašas teritorijas līdz Gaujas ielejai, kas kalpo kā savdabīga barjera, jo otrpus tai purvu aizņemtās teritorijas ir ievērojami mazākas. Zemgale ir ar purviem nabadz̄̄oākais Latvijas regions, daudz purvu sastopami Viduslatvijas zemienē. Lielupes kreisajā krastā purvi ļoti izkliedēti, atrodas lielākoties ap ezeriem Lielauces paugurainē un Spārnenes viḷnotajā līdzenumā - piemēram, ap Zebrus un Lielauces ezeru, šie purvi ir apmežoti. Zemie purvi aizṇem 49,3\% no visiem purviem Latvijas teritorijā. Lielākie purvi ir Peikstuḷnīcas-Salas purvs Ludzas un Balvu rajonā, tā platība ir 7606 ha un Sedas tīrelis Valkas apkārtnēe, kur zemā purva platība ir 6300 ha (tīrel̦a kopēja platība 7582 ha) [24].

\section{Latvijas purvu un kūdras izpētes vēsture}

Vēsturiski purvu un kūdras izpēte aizsākusies ar interesi par jaunu teritoriju apgūšanu lauksaimniecībai un mežsaimniecībai un kūdras kā kurināmā ieguvi. Pirmoreiz Latvijā kūdras pētījumi dokumentēti jau 1692. gadā, bet zinātniskie raksti tapuši 18 . gadsimta beigās līdz ar citiem zemes dzịlu pētījumiem [25]. Pirmais kūdras atradņu apkopojums tika izdots 1837. gadā, laika posmā, kad Latvija atradās vēl cariskās Krievijas sastāvā. 20. gadsimta sākumā tika nodibināta Baltijas Purvu kultūras veicināšanas biedrība, darbojās Galvenā kūdras komiteja, kā arī Meliorācijas fonds. Sākot no 1910. gada sākās izmēginājuma staciju izveide (1912. gadā izveidoja staciju Jaunpētermuižas purvā). Pēc Pirmā pasaules kara 1922. gadā Jaunpētermuižas purvu savā pārzin̄ā pārņēma Zemkopības Ministrijas Purvu pētī̌sanas nodaḷa un tika uzsākta nopietna purvu zinātniskā izpēte klimatoloǵiskie un ķīmiskie pētījumi [13]. Nozīmīga purvu zinātnes attīstība sasaistāma ar 1919. gadā dibināto Latvijas Universitāti, kurā tika izveidota Purvu mācības un tehnologijas 
katedra, vēlāk Purvu institūts. Arī Lauksaimniecības fakultātē nodarbojās ar purvu izpēti - šeit darbojās Purvu ekspluatācijas katedra. Pētījumu rezultāti tika likti par pamatu lielāko Latvijas purvu inventarizācijā [13]. 1939. gadā tika nodibināts Zemes bagātību pētīšanas institūts. No 1939. līdz 1946. gadam institūta speciālisti detāli izpētīja 94 purvus, tajā skaitā 35 sapropeļa atradnes. 1943. gadā tika publicēts profesora Pētera Nomala apskats par Vidzemes un Latgales purviem [13]. 20. gadsimta 60. gados kūdras izpētē aktīvi iesaistījās Zinātṇu akadēmijas Kūdras ķīmiskās pārstrādes laboratorijas vadītājs docents Nikolajs Brakšs [26]. 1962. gadā Latvijas Hidrotehnikas un meliorācijas institūts izveidoja Latvijas PSR Kūdras fondu pēc izpētes datiem uz 1962. gada 1. janvāri. No 1976. līdz 1980. gadam Latvijas Valsts Meliorācijas projektēšanas institūts veica Kūdras fonda inventarizāciju. Tika izveidots Latvijas PSR Kūdras Fonds pēc inventarizācijas datiem uz 1980. gada 1. janvāri. Visa šì darba rezultātā šobrīd ir apzinātas, dažādās pakāpēs izpētītas un sistematizētas 6763 Latvijas kūdras atradnes, kuru kopējā platība ir 10,4\% no pašreizējās valsts teritorijas [23]. 1978. gadā Latvijas Ģeolog̣ijas pārvaldē izveidoja Kūdras partiju, lai meklētu jaunas kūdras atradnes un veiktu jau esošo atradņu revīziju [27]. 1979. gadā Rīgas Civilās aviācijas inženieru institūta zinātnieki pirmoreiz kūdras izpētē izmēgeināja radiolokācijas zondēšanu, tā iegūstot augstas precizitātes vertikālu kūdras profila griezumu ar slāņu biezumiem, saguluma apstākḷiem, minerālo pamatni utt. [28].

Mūsdienās kūdras kā izejmateriāla pētījumi ir kḷuvuši mazāk aktuāli (neskaitot jaunākos pētījumus par kūdru kā sorbentu). Lielākā uzmanība tiek pievērsta purva biotopu izpētei.

Kūdra kā kurināmais tiek izmantota jau vairāk nekā 2000 gadu un tā bija kā saprātīga alternatīva malkai mērenajos un ziemel̦u reǵionos Eiropā, sevišksi İrijāa, Anglijā, Nīderlandē, Vācijā, Zviedrijā, Polijāa, Dānijā un bijušajā PSRS. Naftas un gāzes izmantošanas pieaugums 20. gadsimtā sekmēja kūdras izmantošanas samazināšanos. Tomēr lielās prasības pēc elektroenerǵijas lokāli stimulēja lielu elektrostaciju izveidi, kuras tika darbinātas ar kūdru. Kūdra ir sevišksi konkurētspējīga ar citiem kurināmajiem 60 - 200 MW jaudas elektrostacijās [29].

Latvijā un pasaulē kūdra tiek izmantota un iegūta daudz mazākā apjomā nekā tas būtu ekonomiski pamatoti, neapdraudot dabas vērtības un aizsargājamās dabas teritorijas. Kūdras energoefektivās īpašības netiek pietiekoši novērtētas, un bieži vien tiek izmantoti analogi risinājumi - fosilais kurināmais. Jāṇem vērā, ka kūdra ir vietējas izcelsmes dabas resurss, kas varētu sekmēt neatkarīgu valsts ekonomiku, tomēr Latvija vairāk nekā 90\% iegūtās kūdras eksportē uz dažādām pasaules valstīm. Interesanti, ka, lai arī Latvija ir samērā bagāta ar kūdras purviem, tomēr kūdra tiek arī importēta, galvenokārt no Igaunijas [23].

\section{KŪDRAS TIPI}

Kopumā kūdra ir organogēns eluviāls nogulumiezis, kas gaissausā stāvoklī satur vairāk nekā $50 \%$ organisko vielu, nereti to ietver humītu grupā kā degošu derīgo izrakteni (kaustobiolīts). Kūdra sastāv no augu atliekām ar dažādu sadalīšanās pakāpi, karbonātiskajām un minerālajām daḷināam.
Kūdra veidojas bioķīmisko humifikācijas procesu rezultātā pārmitros apstākḷos. Netraucētā sagulumā kūdrai piemīt augsta saspiežamība un ūdens ietilpība, zems īpatnējais svars un vidēja līdz zema caurlaidība. Kūdras uzkrāšanās notiek ilgstoši mitros apstākḷos uz vāji filtrējošiem cilmiežiem, piemēram, uz māla vai morēnas [3, 30]. Pēc veidošanās apstākḷiem tiek izšķirtas augstā, pārejas un zemā tipa kūdra, kurām katrai, atkarībā no botāniskā sastāva, izdala vairākus (18) apakštipus, no kuriem izplatītākie ir tikai septiņi: koku-grīšlu; koku-hipnu; grīšlı; niedru; kosu; hipnu-zāḷu un zāḷlu. Kūdru mēdz klasificēt arī pēc sadalīšanās pakāpes - maz sadalījusies $(<20 \%)$, vidēji sadalījusies $(20-35 \%)$ un labi sadalījusies $(<35 \%)$. Parasti visaugstākā sadalīšanās pakāpe raksturīga koku kūdrai (līdz 50\%), vismazākā - sūnu kūdrai (ap 5\%). Sadalīšanās pakāpi iespējams noteikt jau lauka apstākḷos, pielietojot L. Posta (Lennart von Post) skalu, taču precīziem rezultātiem izmanto dažādas laboratorijas metodes [31]. Posta skalā kūdras sadalī̌sanās pakāpi iedala 10 grupās: H1 - H10, kur H1 ir pilnībā nesadalījusies kūdra, bet $\mathrm{H} 10$ pilnībā sadalījusies kūdra. Svarīgi, ka šajā skalā kūdru iedala arī pēc mitruma pakāpes: B1- B5, kur B1 ir sausa, bet B5 kūdra ar ļoti augstu mitruma saturu un abas šīs skalas ir lietojamas vienlaicīgi.

\section{Zemā tipa kūdra}

Zemā tipa kūdru parasti veido eitrofo augu atliekas ar augstu sadalīšanās pakāpi. Kūdras krāsa ir l̦oti tumša, līdz melna, kūdras $\mathrm{pH}$ vērtība $\sim 7$. Zemā tipa kūdra sastāv galvenokārt no grīšlu, koku-grīšlıu, koku-zāḷu, hipnu un niedru kūdras slānsiem. Galvenie zāḷu kūdru veidojošie augi ir grǐšlı C. lasiocarpa, C. limosa, C. riparia un niedres Phragmites australis, ko papildina kosu un koku atliekas. Zāḷu purvos kūdras slāṇa biezums ir relatīivi neliels salīdzinājumā ar citu tipu purviem, kā arī vērojama paaugstināta dabiskā mitruma $(>80 \%)$ un augsta mineralizācijas pakāpe (6 - 16\%). Kūdras sadalī̌̌anās pakāpe ir augsta $(20-50 \%$ un vairāk).

\section{Pārejas tipa kūdra}

Pārejas tipa kūdru veido augi dažādā sadalīšanās pakāpē, kas dzīves laikā barības vielas uzņēmuši gan no gruntsūdeņiem, gan nokrišņiem (mezotrofi apstākḷi). Sadalīšanās pakāpe ir atkarīga no veǵetācijas rakstura - no vidējas līdz vājai. Līdz ar vidējo sadalīšanās pakāpi $\mathrm{pH}$ reakcija 4,5. Krāsa tumša, brūngana. Sastāvā dominē koksnes atliekas, grī̌şıi un sfagni. Pārejas tipa kūdrā visbiežāk izdala koku, koku-grīšlu un koku-zāļu kūdras apakštipus. Pārejas tipa koku-grǐšlu, zāḷu-koku kūdras sastāv no oligotrofas un eitrofas augu valsts, un galvenie tās veidojošie augi ir grī̌șii C. lasiocarpa, niedres Phragmites australis, šeihcērijas Scheuchzeria palustris un priedes Pinus sylvestris.

\section{Augstā tipa kūdra}

Augstā tipa sfagnu, sfagnu-grǐšlu, spilvju-sfagnu un citu apakštipu kūdras veidojas un uzkrājas purvu kupolos pēdējā purva attīstības stadijāa, kad veǵetācija barojas vairs tikai no nokrišņu ūdens. Raksturīga zema sadalīšanās pakāpe, tādēl tas ir visskābākais kūdras tips, $\mathrm{pH} \sim 3$. Kūdras krāsa gaiša, dzeltenīgi brūna. Dabiskā minerālo daļiņu koncentrācija niecīga vai tās nav vispār. Sastāvā dominē dažādu sugu sūnu atliekas un koksne. Augstā tipa sfagnu, sfagnu-grīšlu, spilvjusfagnu kūdras veido galvenokārt Sphagnum magellanicum, 
Sph. fuscum, Sph. cuspidatum, Sph. angustifolium, Eriophorum vaginatum un Ericaceae dzimtas sīkkrūmu un priedes makroatliekas, var tikt nodalītas arī augstā tipa grīšlu, zāļu vai koku kūdras.

\section{KŪDRAS FIZIKĀLĀS UN KĪMISKĀS ĪPAŠĪBAS}

Dabīgais kūdras mitrums parasti svārstās 85 - 95\% robežās [32]. Kūdras nogulumu fizikālās īpašības mainās atkarībā no tās botāniskā sastāva, minerālā sastāva, kā arī sadalīšanās pakāpes. Pēc kūdras botāniskā sastāva izšķir koku, koku-sūnu, zāḷu, zāḷu-sūnu un sūnu kūdras grupas [18], tās papildus raksturo kūdras sadalīšanās pakāpes izvērtēšana [5], kas l̦auj pietiekami detalizēti rekonstruēt senās fitocenozes. Viens no kūdras sadalīšanās intensitātes svarīgākajiem faktoriem ir purva skābums - to nosaka purva baktērijas un pH līmenis. Augu sadalīšanās procesi ir iespējami pie gandrīz visiem $\mathrm{pH}$ līmeniem, tomēr skābā vidē baktēriju darb̄̄ba nav tik intensīva, tāpēc sadalīšanās procesi būs lēni, šì principa pamatā augstā tipa kūdras vide ir ideāli piemērota mumifikācijai, un pirmatnējās kopienās purvi tikuši izmantoti upurēšanas rituālos [33].

Augu sadalīšanās ir bioķīmisku procesu virkne, kas norisinās sākumā bioloǵiski l̦oti aktīvo aerobo, vēlāk pasīvāko anaerobo mikroorganismu iespaidā, veidojoties amorfai organiskai vielai - humusam. Kūdras bioķīmiskā degradācija norit, izdaloties metānam un og̣̦skābajai gāzei. Degradācijas procesā veidojas humusvielas (augstmolekulāri polikatjonīti), kurām ir augsts noturīgums vidē. Atkarībā no šksīīibas un molekulmasas tās iedala humīnskābēs un fulvoskābēs [34]. Kūdras sadalīšanās pakāpe jeb humifikācija nosaka konkrēta kūdras nogulumu parauga sadalījušās daļas (humusa) masas attiecību procentos pret kopējo parauga masu. Tā ir cieši saistìta ar citām īpašībām: siltumvadītspēju, blīvumu, viskozitāti utt. [32, 35]. Kūdras sadalīšanās pakāpe ir atkarīga no botāniskā sastāva. Visaugstākā sadalīšanās pakāpe raksturīga dažādām koku kūdrām, savukārt vismazākā zāḷu, grīșlu un niedru kūdrām. No kūdru veidojošo augu daļinu izmēra atkarīgas kompresijas iespējas, viendabīgās zālu kūdras jau formējoties uzkrājas relatīvi kompaktā stāvoklī, kamēr koku kūdrā dažāda izmēra daļinas laika gaitā tiek intensīvi pakḷautas saspiešanai. Zemāk ieguḷošie kūdras slāņi tiek pakḷauti lielākam spiedienam nekā virsējie slāņi, tādēḷ tie ir blīvāki un ir mazākas iespējas izskalošanās procesiem. Sadalīšanās process ir iespējams visos $\mathrm{pH}$ vides līmeños, taču skābā vidē baktēriju darbība nav intensīva, līdz ar to sadalī̌sanās process ir l̦oti lēns [33]. Kūdrai ir augsta sadalī̌sanās pakāpe, ja organisko masu veido vismaz $35 \%$ sadalītu augu atlieku [36]. Sūnu (augstā tipa) kūdrai sadalīšanās pakāpe ir robežās no 5 līdz 13\%, kas ir zemākais rādītājs starp kūdras tipiem. Zāļu (zemā tipa) kūdras sadalīšanās pakāpe parasti ir virs 27\%. Visaugstākā sadalī̌sanās pakāpe raksturīga zemā tipa koku kūdrai - dažos gadījumos pat virs 55\% [37]. Kūdras sadalīšanās pakāpe atkarīga arī no gruntsūdeņiem purvā - ja līmenis ir zems vai ir būtiskas līmeņa svārstības, tad sadalīšanās pakāpe būs augsta, bet, ja ūdens līmenis ir augsts un lielākoties nemainīgs, tad sadalīšanās pakāpe būs zema. Arī temperatūra ietekmē kūdras sadalī̌sanās pakāpi un pie augstākas temperatūras vērojams intensīvāks sadalīšanās process. Kūdras mitrums raksturo ūdens daudzumu, kas izteikts procentos no kopējā kūdras parauga masas. Tas ir atkarīgs no iegulas tipa un kūdras sadalīšanās pakāpes [18]. Novērojama likumsakarība - jo augstāks būs mitrums, jo zemāka sadalīšanās pakāpe (mitrums kavē oksidēšanās procesus). Dabiskais mitrums purvos var sasniegt 95 - 98\%. Organiskās vielas saturs raksturo pagātnes veǵetāciju, tās daudzveidību un izplatības apjomus. Arī šis parametrs ir atkarīgs no purva barošanās apstākḷiem - ja pastāv eitrofi apstākl̦i, tad intensīvāka augāja producēšanās un rezultātā vairāk organiskās vielas kūdrā. Karbonātiskās daļinas kūdrā saistìtas ar augu atliekām, kuras tās satur, kā arī ar karbonātiskiem gruntsūdeņiem. Tomēr šīm daḷiņām pazemes un virszemes ūdeņu ietekmes rezultātā ir tendence izskaloties - gruntsūdens tās var gan piegādāt, gan arī izskalot. Minerālās dalinạas kūdras slāṇos nonāk eolo procesu rezultātā, tiek atnestas ar ūdeņiem utt., daudzos gadījumos veido t.s. ienesto pelnainību. Kūdras pelnainība raksturo minerālo daļinu daudzumu procentos gaissausas kūdras paraugā. Izšķir 2 pelnainības veidus: konstitucionālo pelnainību (minerālo daļiņu saturs augu atliekās, kas zemā purva kūdrā sastāda 4 $9 \%$, bet augstā purva kūdrā 2 - 3\%); ienesto pelnainību (minerālo daḷiņu saturs, kuras tiek atnestas ar vēju, gruntsūdeņiem, vai ūdeņiem, kas periodiski applūdina purva teritoriju, var sasniegt 70 - 80\% no kūdras kopējās masas) [18].

\section{KŪDRAS GALVENĀS IZMANTOŠANAS NOZARES}

Kopš 12. un 13. gadsimta kūdra kḷuva par vienu no nozīmīgākajiem energoresursiem Eiropā [38]. Kopš 17. gadsimta sākuma kūdru sāk izmantot kā kurināmo tekstilrūpniecībā, māla trauku izgatavošanā, alus darināšanā, kā arī augsnes uzlabošanā, bet 18. gadsimta 30. gados tirgū ienāk jauns produkts - Holandes kūdras pelni. Šie pelni tika iegūti pēc kūdras dedzināšanas mājas apkurināšanā, pelniem bija raksturīgs augsts sāḷu saturs, tādejādi tie tika izmantoti kā mēslojums. Šis produkts plašu popularitāti ieguva Holandē, Anglijā, Francijā un Beḷgijā. 19. gadsimtā Vācijā tiek izstrādāta jauna kūdras ieguves un preses tehnoloǵija - tiek izgatavotas pirmās kūdras briketes. 20. gadsimta 30. gados tiek apzināta kūdras vērtība dārzkopībā, tiek izstrādāta jauna kūdras ieguves metode ar vakumsūkṇiem [39]. Mūsdienās, 21. gadsimtā, kūdras izmantošana par vienkāršu kurināmo ir apsīkusi, izṇemot valstis, kur tā ir saglabājusies kā tradīcija, piemēram, Norvēǵijā vai Īrijā. Kanādā visi kūdras krājumi rezervēti primāri dārzkopības pielietojumiem [39]. Skotijā gabalkūdra tiek izmantota skotu viskija izgatavošanas procesā. Miežu iesals tiek žāvēts kūdras dūmos, kas skotu viskijam piedod savdabīgo dūmu aromātu [40]. Purvi, kas izvietoti gar jūras krastu Malaizijā, kalpo kā dabiska barjera plūdu ietekmes mazināšanai, jo kūdra absorbē ūdeni, tomēr šāds pielietojums ir mazefektīvs apmežotajās teritorijās kūdras ugunsnedrošīibas dēḷ [41].

\section{Purva konservējošo īpašĭbu un ūdens izmantošana}

Kūdras purvi ir labi pazīstami unikālo konservēšanas īpašību dēḷ. Kūdra uzglabā organisko materiālu relatīvi neskartu skābekḷa trūkuma dēḷ, kā arī kūdrā esošā tanīna dēḷ. Organiskā viela var tikt tieši uzglabāta kūdrā vai arī apstrādāta 
ar kūdras ekstraktiem. Tomēr kūdras mikrobiālās aktivitātes dēḷ, netiek rekomendēts to izmantot tiešā veidā.

\section{Küdras izmantošana tekstilrūpniecībā}

Kūdras škiedra pārsvarā tiek iegūta no sadalītajām spilvju atliekām (lapu fragmenti, kātiņi) [42]. Tekstilrūpniecībā tiek izmantota arī mūsdienu purvu veǵetācija - no spilvju ziediem tiek veidots pildījums spilveniem un dīvāniem. Tomēr kūdras šķiedras ierobežojums ir nepiemērotība vērpšanai [43]. Pirmā Pasaules kara laikā kūdras šķiedra tikusi izmantota vācu armijas formu un apsēju izgatavošanā [43]. Apǵērbi no kūdras šķiedras - $(50 \%$ kūdras šķiedra $+50 \%$ vilna $)$; futlāri telefoniem, somas. Valkājot apǵērbus, kas veidoti no kūdras škiedras iespējams samazināt diskomfortu (svīšana), kas rodas valkājot, piemēram, sintētiskos tekstilizstrādājumus Ķermeņa svīšana notiek, jo sintētiskās šķiedras nenodrošina pietiekamu ventilāciju. Kūdras tekstilizstrādājumiem šādu trūkumu praktiski nav. Kūdrai ir liela īpatnējā virsma, tādēl̦ šķiedras ir brīvi sasaistîtas un l̦oti vieglas. Kūdras šķiedra absorbē mitrumu, tajās esošo humīnskābju koloidālās dabas dēḷ. Kūdras šķiedra faktiski darbojas līdzīgi kā sūklis - uzņemto ūdeni ir iespējams izspiest. Kūdras humīnskābes arī ir atbildīgas par tās spēju absorbēt dažādas smakas, sāļus un sviedrus. Tekstilizstrādājumos kūdras šķiedra tiek kombinēta ar vilnu attiecībā apmēram 40:60 vai 50:50. Pozitīvais kūdras tekstilizstrādājumos ir tas, ka kūdrai praktiski nav elektrostatiskā lādiņa, kā tas ir piemēram, kokvilnas un vilnas izstrādājumiem. Kūdras humīnskābju sastāvā ir melanīns, kas ir zināms arī kā ādas brūnais pigments. Š̀̃ viela aizsargā pret saules ultravioleto starojumu [43].

\section{Küdras izmantošana pakaišiem}

Kūdra jau gadsimtiem tiek izmantota kā materiāls pakaišiem. Kūdras pakaišu nozīme vienmēr ir bijusi sanitāro apstākḷu nodrošināšana mājlopu uzturēšanās vietās. Visbiežāk pakaišiem izmantota augsta tipa sfagnu sūnas kūdra, jo tai raksturīga augsta mitrumietilpība un tā spēj neitralizēt nepatīkamos aromātus.

\section{Kūdras izmantošana pārtikas pārvadāšanai}

Daudzviet pasaulē kūdra tikusi izmantota kā iepakojuma materiāls augḷu un dārzeṇu pārvadāšanā - saglabājot tos svaigus un nedeformētus.

\section{Kūdras izmantošana energétikā}

Frēzkūdra ir tikusi un tiek izmantota kā kurināmais enerǵētikā, atsevišksās valstīs kūdra tiek izmantota mājsaimniecībās kā alternatīva malkai. Kā piemēru var minēt Īriju vai Skotiju, kuru klinšainajās teritorijās apmežojums ir niecīgs, savukārt ir vērā ņemami kūdras krājumi, tādēl viensētās kūdra tiek lietota krāsns kurināšanai. Kūdrai kā kurināmajam ir rūpnieciska nozīme arī Somijā. İrijai ir raksturīga plaša kūdras izmantošana gan industriāli, mājsaimniecībās. Elektrostacijās tiek izmantota frēzkūdra, savukārt kūdras briketes, kas lielākoties nedūmo kurināšanas laikā, plaši izmanto Īrijas pilsētās, kur ogḷu kurināšana ir aizliegta [44].

\section{Küdras izmantošana ūdensaimnecībā}

Kūdru var izmantot kā ūdens mīkstinātāju akvārijos, kūdra satur vielas, kas ir nozīmīgas ūdens augu attīstībā un zivju reproduktīvajai sistēmai, ar kūdru iespējams limitēt aļǵu izplatību un iznīcināt mikroorganismus. Kūdru iespējams izmantot ūdens filtrācijā [45].

\section{Kūdras pirolīze un ķīmiskā pārstrāde}

Kūdras organiskā viela ir uzskatāma par vērtīgu ķīmisko izejvielu, visai daudzveidīga produktu klāsta ražošanai. Kā galvenos kūdras ķīmiskās pārstrādes virzienus ir jāmin hidrolīzi, pirolīzi, ekstrakciju, termisko šķ̄indināšanu un ķīmisko modifikāciju. Kūdras hidrolīze ir metode, kas l̦auj no kūdras iegūt produktus ar bioloǵisku aktivitāti. Kūdras hidrolizātos ir atrodams plašs aminoskābju, karbonskābju, uronskābju, humīnskābju un citu organisko, bioloǵiski aktīvo savienojumu klāsts. Ekstrakcija ir metode, kas l̦auj iegūt kūdras vasku: vielu ar vērtīgām fizikālajām īpašībām ar plašām pielietojuma iespējām rūpniecībā, medicīnā un citur [46]. Kūdras pirolīze ir metode, kas l̦auj sadalīt kūdras organisko vielu koksā, šķidrajā kurināmajā un deggāzē, turklāt rezultātā, iegūtā kurināmā enerǵētiskā vērtība ievērojami pārsniedz izejas kūdras rādītājus. Tāpat šajā procesā ir iegūstami naftas sorbenti un aktīvās ogles. Arī citiem pirolīzes procesa produktiem: darvām un darvu ūdeņiem piemīt zināma vērtība un saimnieciskā pielietojuma potenciāls. Šķidrā kurināmā ieguvei no kūdras ir iespējams izmantot arī termiskās šksīdināšanas procesu, kas līdzīgi kā pirolīze, l̦auj iegūt produktus ar lielāku enerǵētisko vērtību, kā izejas kūdrai [46, 47].

\section{Küdras izmantošana celtniecībā}

Kūdras masai pievienojot dažādas saistvielas, ir iespējams izgatavot dažādus celtniecības materiālus. Tā, piemēram, kūdru sajaucot ar darvu un ğipsi ir iespējams izveidot izolācijas materiālus. 17. un 18. gadsimta Îrijā trūcīgās ǵimenes izmantojušas žāvētas kūdras blokus mājokḷu būvniecībai. Latvijā viens no dabiskajiem materiāliem, kuru var pielietot siltumizolācijas materiālu ražošanā, ir kūdra, jo kūdra ir salīdzinoši lēts un viegli pieejams materiāls [48].

\section{Kūdra kā filtrācijas materiāls un biosorbents}

Kūdras fizikālās un ķīmiskās īpašības: attīstīta porainība, liela īpatnējā virsma, jonu apmaiņas spēja un citas, padara kūdru par augstvērtīgu materiālu dažādu sorbentu izgatavošanai. Kūdru visai tradicionāli izmantoto par filtru dažādām gāzēm un šķidrumiem. Pasaulē ir zināmas visai attīstītas biofiltrācijas sistēmas, kurās tiek izmantota kūdras šķiedra. Kūdras šķiedrai raksturīgs liels virsmas laukums, tādējādi padarot kūdru par kvalitatīvu sorbentu mikrobiem un dažādām ķīmiskajām vielām. No kūdras tiek izgatavota arī aktivētā ogle. Termiski apstrādāta kūdra absorbē dažādas elıısas, taču neabsorbē ùdeni - ar šādu preparātu iespējams attīin̄t ūdeni no naftas piesārņojuma. Kūdru iespējams izmantot kā gaisa filtru.

Kūdra var tikt izmantota kā efektīvs, bet tajā pašā laikā lēts, viegli pieejams un viegli izmantojams biosorbents, kas efektīvi saista ķīmiskos elementus un to savienojumus no dažāda veida piesārṇotiem ūden̦iem. Šie ūdeṇi visbiežāk ir komunālie notekūdeņi, bet pētîjumi parāda, ka kūdru var veiksmīgi izmantot arī piesārņotu gruntsūdeņu, lauksaimnieciskās ražošanas notekūdenuu un atkritumu izgāztuvju infilitrāta attīrīšanā. 
Lai apzīmētu kūdras (un arī citu bioloǵiskas izcelsmes materiālu) spēju attīīit piesārṇotus ūdeṇus, tiek lietots termins „sorbcija” vai ,biosorbcija”. Jāuzsver, ka termins „, biosorbcija” apvieno vairākus mehānismus, kas nodrošina kūdras spēju attīrīt piesārṇotos ūdeņus. Šie mehānismi ir ne tikai adsorbcija un/vai absorbcija, bet arī jonu apmaiņa, kompleksu veidošanās un izgulsnēšanās. Ja kūdra tiek izmantota smago metālu sorbcijai, tad jonu apmaiņa ir noteicošais mehānisms - kūdras humifikācijas procesa laikā rodas humusvielas, kas satur karboksilgrupas un fenolu hidroksilgrupas, kuras reakcijā ar metāliem atbrīvo protonus.

Biosorbentu, t.sk. arī kūdras izmantošanas nepieciešamību nosaka tas, ka tradicionālām attīrīšanas metodēm piemēram, izgulsnēšanai ar karbonātiem vai hidroksīdiem, jonu apmaiņai un reversajai osmozei, piemīt vairāki trūkumi - lielas izmaksas (līdz ar to samazinās uzṇēmuma konkurētspēja), bieži rodas kaitīgas dūņas un šīs metodes nav iespējams izmantot, ja ūdenī ir zemas piesārn,ojošo vielu koncentrācijas. N̦emot vērā minētās nepilnības, ir nepieciešams izmantot jaunus tehnoloǵiskos paṇēmienus, kuri būtu lēti un efektīvi. Tā kā minētajam nosacījumam labi atbilst kūdras izmantošana, tad ir veikti daudzi pētījumi, kuros ir noteiktas kūdras sorbcijas spējas un šo spēju ietekmējošie faktori [49].

Smagie metāli (piemēram, svins, varš, kadmijs, cinks, hroms) ir viena no visbiežāk pētītajām piesārņotāju grupām biosorbcijas pētījumos, jo tie atrodas daudzos rūpniecības notekūdeños, līdz ar to radot draudus gan ekosistēmām, gan cilvēka veselībai, jo ir toksiski jau zemā koncentrācijā, nav biodegradējami un daudzi no tiem var būt kancerogēni. Pētījumi parāda, ka kūdra ir viens no efektīvākajiem smago metālu biosorbentiem. Kūdras spēju sorbēt smagos metālus, nodrošina kūdras fizikālķīmiskās īpašības, piemēram, augstā katjonu apmaiņas kapacitāte, lielā porainība un īpatnējās virsmas platība [50]. Kūdras sastāvdaḷas, īpaši lignīns, satur funkcionālās grupas, piemēram, spirtus, aldehīdus, skābes, fenolkarboskābes un ēterus, kuras var iesaistīties smago metālu sorbcijā [51]. Šo funkcionālo grupu sastāvs kūdrā ir atkarīgs no kūdras īpašībām un tās veidošanās apstākḷiem (piemēram, vecuma, veǵetācijas, no kuras kūdra ir veidojusies, klimata, ūdens pH) [52]. Jāuzsver, ka kūdras sorbcijas spēju ietekmē ne tikai pašas kūdras īpašības, bet arī notekūdeṇu fizikālās un ķīmiskās īpašības, piemēram, metāla koncentrācija ūden̄i, $\mathrm{pH}$, temperatūra un citu vielu klātbūtne. Līdzšinējie pētījumi parāda, ka šks̄īuma $\mathrm{pH}$ būtiski ietekmē kūdras sorbcijas efektivitāti - izmantojot kūdru notekūdeṇu attīrī̌sanā, lielāka efektivitāte ir sagaidāma pie lielākām pH vērtībām kā zemām [53]. Tas ir izskaidrojams ar to, ka pie zemākām $\mathrm{pH}$ vērtībām $\mathrm{H}^{+}$jons konkurē ar metāla katjoniem par adsorbcijas saitēm sistēmā. Samazinot $\mathrm{H}^{+}$jonu daudzumu šķ̄idumā (t.i., palielinot pH), tas nozīmē, ka samazinās „konkurence” par jonu apmaiņu šks̄idumā ar jonu apmaiņu sorbentā, rezultātā palielinās sorbcijas kapacitāte [54].

Lai uzlabotu kūdras sorbcijas efektivitāti un novērstu vai samazinātu vairākus trūkumus, piemēram, kūdras zemo mehānisko izturību, zemo ķīmisko stabilitāti, ir iespējams kūdru modificēt - tiek veikta fizikāla vai ķīmiska sorbenta priekšapstrāde. Izmantotās fizikālās metodes ir karsēšana, autoklāvēšana vai liofilizācija, savukārt ķīmiskās metodes ir apstrāde ar skābēm, sārmiem vai organiskajām ķimikālijām. Kūdras sorbentu ir iespējams sagatavot arī granulu veidā, tādā veidā nodrošinot labāku piesārṇoto ūdenuu caurplūdi, kā arī tiek samazināta iespēja sistēmai aizsērēt kūdras dalinunu mazā izmēra dēḷ.

Minēto materiālu pieejamība konkrētā vietā tiek minēta kā galvenais faktors biosorbentu izvēlē, līdz ar to Latvijā, kurā ir lieli kūdras resursi, būtu perspektīvi izmantot kūdru piesārṇotu ūdeṇu attīrīšanā.

Kūdras sorbenti var tikt izmantoti, lai attīìitu notekūdeņus no fosfora un slāpekḷa savienojumiem [55], kā arī dažādām organiskajām vielām, piemēram, poliaromātiskajiem ogḷūdeņražiem [56, 57].

Lai uzlabotu kūdras sorbcijas kapacitāti, to iespējams dažādos veidos modificēt, piemēram, ar dzelzs savienojumiem modificēta kūdra spēj ievērojami palielināt sorbcijas kapacitāti, sorbējot arsēna un fosfora savienojumus. Ar dzelzs savienojumiem modificētu kūdru efektīvi iespējams izmantot metalōidu (As, Sb, Te) savienojumu sorbcijai. Metallō̄diem sorbējoties uz dzelzs modificētas kūdras, sorbcijas mehānisma pamatā iespējams ir metalō̄ds - O - Fe (piemēram, As - O Fe) saites veidošanās. Savukārt karboksil-, hidroksil- un aminogrupas iespējams ir galvenās funkcionālās grupas, kas var mijiedarboties ar metalōidiem, izmantojot nemodificētu kūdru. Kūdra ir viens no daudziem dabiskiem materiāliem, ko modificējot, ir iespējams iegūt sorbentu. Kūdras sorbentu sorbcijas kapacitāte, sorbējot metalō̄dus, ir salīdzināma ar citu dabas materiālu, piemēram, ar dzelzs oksīdu klātām smiltīm [58], modificētu biomasu [59], sorbcijas kapacitātēm. Tomēr, lai salīdzinātu dažādus sorbentus, svarīgi ir tādi parametri kā izmantotais sorbenta daudzums, metaloīda koncentrācija, $\mathrm{pH}$ un citi parametri, kas būtiski ietekmē sorbcijas kapacitāti.

Kūdras sorbentiem ir visai vienkārši piešķiramas nepieciešamās īpašības: uz to bāzes ir iespējams radīi kā hidrofîlus sorbentus izmantošanai ūdens šksīumos, tā arī hidrofobus, dažādu organisko savienojumu (el̦las vai naftas produktu) sorbcijai. Tāpat no kūdras ir iespējams izgatavot tādu plaši pielietojamu produktu kā aktivētā ogle [46].

\section{Kūdras izmantošana lauksaimniecībā un dārzkopībā}

Gan sūnu kūdra, gan frēzkūdra tiek izmantotas dārzkopībā kā augsnes uzlabotāji. Kūdra ir sekmīgi izmantojama lauksaimniecībā, sajaucot kūdru kopā ar augsni var ievērojami uzlabot tās struktūru un paaugstināt skābuma pakāpi. Viena no galvenajām kūdras lauksaimnieciskajām īpašībām ir spēja saglabāt mitrumu, kad augsne ir sausa, tādējādi saglabājot ūdens pieeju augiem. Kūdra tiek plaši izmantota arī dārzkopībā, tikai šajā gadījumā tiek rekomendēts kūdru pirms tam termiski apstrādāt, lai iznīdētu kaitēkḷus un reaktīvās barības vielas.

\section{Küdras izmantošana ārstniecība}

Pagājušajā gadsimtā kūdras pelni tikuši izmantoti kā piedeva mājlopu barībai, tika uzskatīts, ka kūdras piedeva barībai paildzina tās sagremošanu un lauj dzīvniekiem no pārtikas uzñemt vairāk barības vielu. Interese par kūdru kā piedevu lopbarībai pēdējos gados ir pieaugusi, dal̦ēji tādēl, ka tā spēj ierobežot dažādas zarnu slimības un stimulēt sivēnu un cūku augšanu. Kūdras preparātu pozitīvā ietekme uz dzīvnieku organismu (imūnsistēmas nostiprināšana, detoksikācija u.c.) tiek skaidrota ar augsto humusvielu saturu kūdrā. Kūdras preparāti tiek izmantoti kā pārtikas piedeva lopbarībai, lai 
mazinātu kungga un zarnu saslimšanu risku jaunlopiem. Augstā tipa kūdras zemais $\mathrm{pH}$ līmenis stabilizē jaunlopu kunğu mikrofloru [60], kā arī ierobežo dzīvnieku patogēno baktēriju attīstību.

Kūdru iespējams izmantot balneologijāa, populārākie pielietojumi ir kūdras kompreses, vannas, kūdras maskas. Kūdra tiek izmantota fizioterapijā, reimatologijā un sporta medicīnā. Kūdrai raksturīga zema siltumvadītspēja un daudz augstāka siltuma saglabāšana nekā citiem materiāliem, ko izmanto fizioterapijā. Izmantojot kūdras preparātus fizioterapijā, ir iespējams ārstēt muguras sāpes, artrītu, ortopēdiskās saslimšanas un neirologiiskos traucējumus. Sporta medicīnā kūdras paketes tiek izmantotas uz dažādām ķermeņa daḷām, lai tās pārkarsētu, tādējādi paaugstinot asins cirkulāciju un veicinot vielmaiņas atkritumvielu iznīcināšanu [60].

\section{KŪDRAS HUMUSVIELAS}

Humusvielas ir biologiiski noturīgas, lielmolekulāras, heterogēnas uzbūves dabiskas izcelsmes organiskas vielas ar plašu krāsu spektru (no dzeltenas līdz melnai) [61]. Humusvielas veido nozīmīgu daļu kūdras organisko nogulumu. Humusvielu vecums atkarībā no to atrašanās vietas var būt l̦oti dažāds. Humusvielu, kas atrodas kūdras sastāvā, vecums var būt no dažiem simtiem līdz pat 10000 gadiem [62]. Molekulu izmērs var svārstīties no 400 lìdz pat 1000000 oglekḷa vienībām - daltoniem. Humusvielām piemīt izteikta spēja veidot kompleksus ar metāliem, spēja šķīdināt hidrofobas organiskas vielas, kā arī samazināt šķ̄īdumu virsmas spraigumu. Tāpēc humusvielas var būtiski ietekmēt vides īpašības, arī biologisko procesu norisi tajā [63].

Pēc šķīīibas pakāpes ūden̄̄ ir trīs frakcijas: humīns humusvielu (HV) frakcija, kas nešksīst ūden̄i; humīnskābes (HS) - HV frakcija, kas škīist ūden̄i, ja $\mathrm{pH}>2$; fulvoskābes (FS) - HV frakcija, kas šks̄ist ūdenī, pastāvot jebkuram $\mathrm{pH}$ [64].

Humusvielas var veidoties dažādās vidēs, un šādām humusvielām ir autohtona izcelsme, vai arī tās var tikt ienestas no saistītām vidēm (alohtonā izcelsme), piemēram, augsnes humusvielām ieskalojoties virszemes vai pazemes ūdeņos [64].

Humusvielas veidojas sekundārās sintēzes (humifikācijas) rezultātā, satrūdot un transformējoties biomolekulām, kas veidojušās no atmirušiem organismiem mikroorganismu iedarbībā uz organiskajām atliekām. Humifikācija ir l̦oti sarežğîts bioḳīmisks process (augu un dzīvnieku atlieku sadalīšanās, organisko vielu mineralizācija, mikroorganismu iedarbība uz organiskajām atliekām u.c.), kuras rezultātā notiek organisko vielu sadalī̌̌anās, tālāka transformācija un akumulācija kādā no vidēm [65].

\section{Humusvielu nozīme vidē}

Humusvielu uzbūve l̦auj tām mijiedarboties ar dažādu vielu grupām, piemēram, neorganiskajiem joniem, veidojot sāļus un kompleksus savienojumus, kā arī ar hidrofobām organiskām vielām [64, 66]. Humusvielu spēja aktīvi mijiedarboties ar dažādām vidē esošām vielām nosaka to lielo nozīmi dabā noritošajos procesos, bet vienlaikus n,emot vērā to lielo masu dažādās vidēs (augsnē, kūdrā), tās spēj būtiski ietekmēt pašas vides īpašības, arī biologisko procesu norisi tajā [67].
Humusvielu nozīmīgākās īpašības vidē norisošajos procesos ir šādas: 1) noturība pret ķīmisko un bioloǵisko degradāciju humusvielas ir noturīgas pret mikrobiālo degradāciju, tādēl to vecums var sasniegt pat 10000 un vairāk gadu [61, 68]; 2) humusvielas ir stabilas arī attiecībā pret vidē sastopamo skābju, bāzu un oksidētāju iedarbību. Intensīva humusvielu degradācija notiek fotoḳīmiski, sevišksi katalizatoru klātbūtnē [69]; 3) spēja saistîties ar augsnes un ūdens minerālajiem komponentiem un organiskajiem savienojumiem [61], kas ietekmē piesārn,ojošo vielu migrācijas raksturu [65]; 4) spēja saistīties ar metālu joniem - humusvielās ir augsts tādu funkcionālo grupu saturs, kuras nosaka humusvielu spējas veidot savienojumus ar metālu joniem. Tāpēc ar humusvielām bagātos ūdeños metāli galvenokārt atrodas nevis brīivu jonu, bet gan humīnskābju un fulvoskābju sāļu un kompleksu savienojumu veidā [70]. Līdz ar to humusvielas ietekmē metālu (īpaši smago metālu) transportu un atrašanos vidē.

Humusvielu spējai veidot stabilus kompleksus ar augsnes vai ūdens neorganiskajiem un organiskajiem komponentiem ir liela nozīme vides piesārņojuma līmeņa mainībā, kā arī piesārṇojošo vielu transformācijas procesā. Galvenokārt atzīmējamas šādas galvenās humusvielu funkcijas vidē: 1) akumulatīvā funkcija - augsnē uzkrājas ar humusvielām saistītie dzīvo organismu barošanās elementi: 90-99\% N, ievērojama daļa $\mathrm{P}$ un $\mathrm{S}$, kā arī K, Ca, C, Mn, Fe un gandrīz visi mikroelementi; 2) transporta funkcija - to nosaka minerālo un organisko vielu ǵeoķīmisko plūsmu veidošanās, īpaši ūdens vidē, kur veidojas noturīgi, bet relatīvi viegli šķīstoši humusvielu savienojumi ar metālu katjoniem, hidroksīdiem, dažādām organiskajām vielām un alumosilikātiem; 3) regulējošā funkcija nosaka daudzus vidē norisošos procesus: augsnes struktūras un fizikālo īpašību veidošanos, līdzsvara uzturēšanu jonu apmaiņas reakcijās, skābju-bāzu apmaiṇu, augu barošanos (regulē minerālo komponentu šķī̌sanu ūden̄̄ un pieejamību dzīvajiem organismiem), augsnes siltuma režīma regulēšanu (ietekmē spektrālās atstarošanas spējas, augsnes masas siltumietilpību un siltumvadāmību), augsnes ķīmiskā sastāva diferenciācijas procesus; 4) aizsargfunkcija - humusvielas darbojas kā "ǵgeoķīmiskā barjera": aizsargā augsni no sausuma un pārmērīga mitruma, pasargā augsni no erozijas un deflācijas;, saglabā augsnes fizikālās īpašības, pastāvot antropogēnām slodzēm, mazina toksisko vielu negatīvo iedarbību un migrāciju vidē; 5) fiziologiskā funkcija izpaužas galvenokārt kā humusvielu tiešā fizioloǵiskā iedarbība uz augiem un mikroorganismiem [71].

\section{Humusvielu izdalǐšanas metodes}

Humusvielu izdalīšanu no vides apgrūtina tas, ka tās atrodas saistītā veidā gan ar detrītu un citām organiskām vielām (gan mazmolekulārām, gan lielmolekulārām vielām), gan ar neorganiskām vielām un minerāliem. Š̄̄ iemesla dēl loti apgrūtināta ir augsti attīīitu humusvielu paraugu iegūšana, nedegradējot to sākotnējo lielmolekulāro struktūru. Vēl aizvien ir aktuāli pētījumi par humusvielu ekstrakcijas metodēm. Šobrīd ir izstrādāts daudz ekstrakcijas metožu, bet, lai nodrošinātu humusvielu paraugu salīdzināmību, tiek rekomendēts lietot standartmetodes [61], kuru izmantošana nodrošina minimālas humusvielu īpašību izmaiṇas un makromolekulu degradāciju. 
Ideālai ekstrahēšanas metodei no kūdras un augsnes (līdzīgas prasības tiek izvirzītas arī humusvielu izdalīšanai no citām dabas vidēm) jāatbilst četriem kritērijiem: 1) metode nedrīkst mainīt izdalītā materiāla dabiskās īpašības; 2) ekstrahētajām humusvielām jābūt brīvām no neorganiskajiem piemaisījumiem, piemēram, māla daļin̄ām un daudzvērtīgiem katjoniem; 3) ekstrahēšana ir ideāla, ja iegūtas humusvielu frakcijas ar visplašāko molekulmasu spektru; 4) metode lietojama humusvielu izdalīšanai no dažādām vidēm.

Humusvielu ekstrakcijai no cietas fāzes paraugiem izmantojami sārmu metālu hidroksīidi, karbonāti, hidrogēnkarbonāti, pirofosfāti, kā arī citi savienojumi [64]. Visplašāk kūdras humusvielu ekstrahēšanai izmanto $\mathrm{NaOH}$ Šķīdumus [72, 73], jo tie, salīidzinot ar citiem ekstrahentiem, lauj izdalīt 30-60\% augsnes vai kūdras humusvielu. Starptautiskā humusvielu pētnieku savienība (IHSS) iesaka izmantot standartmetodi - ekstrahēšanu ar $\mathrm{NaOH}$ šķīidumu un paskābināšanu ar $\mathrm{HCl}$, kā arī piedāvā standartizētus paraugus ekstrahēšanai no dažādām vidēm.

Humusvielu nešksīstošo frakciju - humīnu galvenokārt veido organiskās vielas, kuras raksturo liels daudzums hidrofobu struktūru. Humusvielu nešks̄istošās frakcijas - humīna izdalīšanai, kā arī attīrīšanai rekomendē augsni, kūdru vai nogulumus apstrādāt ar HCl, HF un HCl-HF šksīidumiem. Šāda veida apstrāde maina organisko vielu ķīmisko struktūru, tāpēc tiek piedāvāta metilizobutilketona metode [74]. Saskan̄ā ar šo metodi pēc ekstrakcijas ar metilizobutilketonu humusvielas tiek izolētas suspensijas veidā. Tādējādi tiek samazināta ekstrakcijas procesa ietekme uz izdalītā materiāla īpašībām.

\section{KŪDRAS HUMUSVIELU IZMANTOŠANAS IESPĒJAS}

\section{Humusvielu izmantošana lauksaimniecībā}

Humusvielas augsnē ir enerǵijas avots tajā mītošajiem organismiem, jo tiem atšķirībā no virszemes augiem nav pieejama enerǵija, kas rodas fotosintēzes procesā. Šis ir iemesls, kāpēc organisko vielu klātbūtnei ir milzīga nozīme augsnē notiekošo metabolisma reakciju nodrošināšanai. Tādi augsnes organismi kā aļǵes, rauga sēnes, baktērijas, sēnes, nematodes, mikoriza u.c. veic tādas būtiskas funkcijas kā augsnes auglības un struktūras uzlabošanu, kā arī veicina augu augšanu un aizsardzību pret dažādām slimībām. Piemēram, augsnē esošās baktērijas rada polisaharīdu kompleksus, ar kuru palīdzību tiek veidotas augsnes picinas (agregāti), uzlabojot augsnes struktūru. Aktinomicētes izdala antibiotikas, kas, uzņemtas augos, l̦auj tiem kḷūt neuzņēmīgākiem pret dažādām slimībām.

Humusvielas ir ne tikai enerǵijas avots augsnē noritošajiem procesiem. Tām ir liela nozīme ūdens piesātinājuma nodrošināšanai un uzturēšanai. Ūdens ir galvenais aǵents augsnēs, kas nodrošina vielu šķ̄išanu, to plūsmu un uzņemšanu augos. Līdzịgas struktūras augsnē humusvielu spēja noturēt ūdeni augu sakņu sistēmas tuvumā ir septiņas reizes augstāka nekā tādas pašas augsnes mālu dalininām. Tāpēc, lietojot humusvielas saturošu mēslojumu, var iegūt augstākas ražas arī ilgstošākos sausuma periodos. Līdz ar spēju ietekmēt ūdens režīmu, tiek nodrošināts arī augsnes temperatūras režīms, kas tiek regulēts ar iztvaikošanas palīdzību [71].

Humusvielas augsnē ir arī efektīvs kompleksveidotājs, kas kopā ar baktēriju radītajiem cukuriem un mālu minerāliem veido kompleksus. Kompleksu veidošana kopā ar spēju ietekmēt mitruma režīmu ir svarīgs augsnes struktūras veidotājs un uzlabotājs. Irdenāka augsnes struktūra uzlabo pārējos augšņu komponentus - gāzu apmaiņu ar atmosfēru, ūdens infiltrāciju u.c., spēja veidot kompleksus būtiski ietekmē arī dažādus toksīnus (nikotīns, fenoli, antibiotikas, aflatoksīns u.c. pesticīdi) ar tiem gan veido kompleksus, gan arī iekļauj tos savā struktūrā, tādējādi samazinot to toksiskumu. Mikrobiālās degradācijas procesu rezultātā veidoto kompleksu pastāvēšanas laiks vidē tiek samazināts.

Humusvielām ir liela nozīme augsnes buferkapacitātes nodrošināšanā, līdz ar to augsnes ir izturīgākas pret paskābināšanos. Humusvielas ietekmē reakcijas ar metālu joniem, samazinot to kustīgumu un toksiskumu, t.i., humusvielu un smago metālu veidotie kompleksi ir mazāk toksiski augiem (piemēram, dzīvsudraba un kadmija savienojumi) vai kompleksa sastāvā kḷūst nešķīstoši (svina savienojumi), tādējādi augi smagos metālus nevar uzṇemt. Uzturot augsnes $\mathrm{pH}$ vērtības tuvu neitrālai reakcijai, tiek nodrošināts, ka Al savienojumi ir nešķīstoši un augi tos neuzṇem savā struktūrā.

HV reakcijas ar metālu joniem nav vērstas tikai vienā virzienā, t.i., tie netiek padarīti tikai augiem neuzņemami. Kompleksi ar tādiem elementiem kā Fe, Cu, Zn, Mg, Mn, Ca kḷūst augiem pieejamāki un pilda mikroelementu funkcijas. Humusvielu regulējošā funkcija augsnē izpaužas arī kā metālu kompleksu - helātu veidošanās ar metālu joniem, elektrostatiski saistot pozitīvi lādētos metālu jonus uz humusvielu virsmas. Rezultātā var tikt kavēta mineralizācija (mazāk veidojas jauni minerāli - piemēram, Fe veidotais ortšteina podzola slānis, kā arī samazinās augsnes sasāļošanas risks), jo augsnēs ar augstu humusvielu saturu samazinās dažādu metālu savienojumu (karbonātu, oksīdu, sulfīdu, hidroksīdu) daudzums. Humusvielu savienojumi pasargā fosfătus no nešķīstošu savienojumu veidošanās, bet augi tos viegli atbrīvo ar dažādām organiskajām vielām, ko izdala to sakṇu sistēmas [71].

\section{Humusvielu nozīme augu augšanas stimulēšanā}

Galvenie augu augšanas stimulējošie faktori ir ūdens piesātinājuma nodrošināšana, augsnes struktūras uzlabošana, spēja saistīt mikroelementus. Vairāki autori savos darbos minējuši, ka humusvielas stimulē augu makroelementu $\mathrm{K}, \mathrm{N}$, $\mathrm{P}, \mathrm{Ca}$ un $\mathrm{Mg}$ uzñemšanu. Iedarbības mehānisms, no vienas puses, darbojas kā kompleksu veidošana, kas samazina vielu šksīdību, tāpēc tās tik ātri neizskalojas no augsnes vai nenokļūst atmosfērā, bet, no otras puses, augiem vieglāk ir uzṇemt organominerālos komponentus. Šīs atziņas ir saskaņā ar pētījumiem, kuros noskaidrots, ka galvenais iemesls straujam biogēno elementu koncentrācijas pieaugumam gruntsūdeņos un ražas apjomu degradācijai ir bijusi humusvielu zemā koncentrācija augsnē.

Veicot salīdzinājumu, kā humusvielas spēj ietekmēt augu sakṇu sistēmas pieaugumu, secināts, ka augiem, kas apstrādāti ar humusvielām vai audzēti ar humusvielām bagātā augsnē, ir par 20-50 \% lielāka sakṇu sistēma, taču tikai pastāvot nosacījumam, ja tiek izmantotas humusvielas ar relatīvi mazu molekulmasu un optimālu to koncentrāciju. Parasti ieteicamā koncentrācija ir 10-100 mg/L. Augu lapu apsmidzināšana ar humusvielām intensificē oĝ̣hidrātu veidošanos augu lapās. 
Humusvielas tādējādi laika gaitā nokḷūst gan augu saknēs, gan augsnē, iedarbojoties kā papildu barības vielas, ko var uzņemt augi vai metabolisma reakcijās iesaistīti augsnes mikroorganismi. Augu lapu apsmidzināšanai paredzētie humusvielu preparāti parasti nepārsniedz koncentrāciju $50 \mathrm{mg} / \mathrm{L}$. Lai gan ir minēti daudzi pozitīvi humusvielu izmantošanas efekti, l,oti augsta to koncentrācija iedarbojas kā metabolisma procesu kavētāji. Par to liecina purvos labi saglabājušās kultūrvēsturiskās vērtības [62].

Pastāv uzskats, ka humusvielas iedarbojas arī uz šūnu membrānām, tādējādi palielinot dažādu elementu plūsmu caur tām. Tā kā humusvielām ir raksturīgas gan hidrofobās, gan hidrofilās struktūras, tiek uzskatīts, ka humusvielas spēj mainīt šūnu fosfolipīdu elektrostatisko lādinu, kas ir atbildīgs par jonu plūsmu. Aplūkojot humusvielu iedarbību šūnu līmeni, ir atrastas sakarības, kas liecina, ka, izmantojot organiskās skābes (humīnskābes, fulvoskābes), ir novērojams informatīvā RNS pieaugums šūnās, kas savukārt atbild par dažādiem bioksīmiskajiem procesiem. Līdz ar to pieaug arī dažādu enzīmu apjoms, kas paātrina vairāku katalītisku reakciju ātrumu, pozitīvi ietekmējot arī ATF sintēzi šūnās.

\section{Humusvielu izmantošana degradētas vides rekultivācijā}

Tā kā humusvielu struktūrā relatīvi augstās koncentrācijās ietilpst karboksilgrupas, hidroksilgrupas, fenoloksilgrupas u.c. funkcionālās grupas, kuras var veidot koordinatīvas saites ar metālu joniem, kā arī kompleksus ar organiskajām vielām, tās ļoti veiksmīgi var izmantot piesārṇotas vides rekultivācijai.

Humusvielu un metālu jonu mijiedarbībai ir liela nozīme tās ietekmē metālu kustīgumu un toksiskumu, tiem nonākot dabas vidē. Ir pierādīts, ka humusvielas nosaka metālu atrašanās formas gan dabas ūdeņos, gan nogulumos. Nozīmīgi, ka tikai $1 / 3$ saistǐšanas kapacitātes nosaka jonu apmaiņas reakcijas, bet pārējās nodrošina kompleksu veidošanas spēja. Humusvielu virsmas platîba ir aptuveni $2000 \mathrm{~m}^{2} / \mathrm{g}$, kas ir ievērojami augstāka par citu vidē esošo minerālu virsmas platību un ir viens no galvenajiem faktoriem, kas ietekmē humusvielu-metālu mijiedarbības intensitāti. Ir pierādīts, ka humusvielas vidē veicina vai ir tiešs cēlonis daudzu metālu jonu reducēšanai, kas ietekmē metālu kustīgumu vidē piemēram, $\mathrm{Fe}^{3+}$ par $\mathrm{Fe}^{2+}, \mathrm{Cr}^{6+}$ par $\mathrm{Cr}^{3+}$. Taču veikti arī pētījumi, kas ir pierādījuši, ka humusvielas pazemes vidē var noteikt apglabātu radioaktīvo vielu kustīguma palielināšanos [75], kā arī paaugstināt Hg kustīgumu piesārṇotās vidēs [76, 77]. Metālu un humusvielu mijiedarbības rezultātā ievērojami samazinās metālu jonu toksiskums [78, 79, 80]. Daudzus humusvielu-metālu kompleksus raksturo būtiski pazemināta šķīīiba salīdzinājumā ar citām dabas vidē sastopamām organiskajām vielām.

Organisko vielu pozitīvā iedarbība un toksiskums dabas vidē ir atkarīgs no to sadalījuma starp dažādiem vides elementiem. Organisko piesārņojošo vielu izplatību dabā ietekmē humusvielas, kuras sastopamas koloīdo daḷiņu un izšķīdušā veidā, kā arī adsorbētas uz augsni un nogulumus veidojošiem minerāliem. Humusvielu un organisko vielu mijiedarbības rezultātā var mainīties to îpašības un iedarbība dabas vidē. Šādu mijiedarbību rezultātā [65] palielinās nejonogēno hidrofobo organisko vielu šksīīiba; samazinās jonogēno organisko vielu šḳīdība; samazinās organisko vielu gaistamība; tiek izmainīta organisko vielu reaǵētspēja; bioakumulācijas intensitāte mainās atkarībā no piesārņojošo organisko vielu daudzuma vidē; palielinās organisko vielu saistīšanas intensitāte ar sedimentu daļin̄ām.

Svarīga daudzu organisko vielu îpašība ir to hidrofobums (vielas tieksme atgrūst ūdens molekulas). Hidrofobo organisko vielu fizikālḳimiskās īpašības ietekmē to biologisko pieejamību. Organiskās vielas, kuras saista humusvielas, ir mazāk pieejamas zooplanktonam, zivīm un bentosa organismiem nekā vielas izšksīidušā formā [65].

Humusvielu un organisko vielu saistīšanās intensitāte ir atkarīga no šo vielu struktūras, kompozīcijas, molekulu lieluma, aromātiskuma pakāpes, koncentrācijām un $\mathrm{pH}$ vērtībām vidē (piemēram, pesticīdu ķīmisko īpašību un sastāva lielā variabilitāte) [81, 82, 83, 84, 85].

Humusvielas un to modifikācijas produktus var izmantot notekūdeņu attīrīšanai, lai tos atbrīvotu no toksiskiem metālu savienojumiem. Tās ļoti veiksmīgi var izmantot aerācijas tankos kā piedevas, lai absorbētu taukus, el̦las, organiskas izcelsmes šksidrumus un suspendēto materiālu. Ir arī l̦oti specifiskas lietojuma jomas, piemēram, izmantot kā polimēru koagulantu piedevu, lai no ūdens izgulsnētu šķistošas organiskās vielas. Humusvielas var izmantot kā piedevu, kas samazina škidrumu zudumus (to skaitā organiskiem šķ̄idinātājiem, urbšanas šksidrumiem utt.) infiltrācijas procesos lagūnās, karjeros un piesārṇotās teritorijās.

Humusvielas ietekmē virsmas spraigumu, jo tām ir liela virsmas platība un to sastāvā ir tādas funkcionālās grupas kā fenolu hidroksilgupas, karboksilgrupas u.c., kas nosaka spēju absorbēt, adsorbēt un selektīvi ekstrahēt dažādus organiskos un neorganiskos materiālus. Izmantojot šīs humusvielu īpašības, tās veiksmīgi var lietot kā specializētus filtrus, ekstrahētājus un šķīdumus hromatogrāfijai. Ļoti plaši var izmantot ūdeņu attīrī̌sanai, kas piesārṇoti ar dažādām suspensijām, eḷ̦ām, metāliem u.c. [86].

Ir pierādīts, ka kūdru un humusvielas var izmantot kā biosorbentus kadmija un cinka saistī̌sanai [87].

\section{Humusvielu biologiskā aktivitāte un to izmantošana medicīnà un farmācijā}

Humīnskābes ir galvenais kūdras organisko vielu komponents, kura ārstējošās īpašības ir pazīstamas kopš senatnes. Kūdras ārstējošā ietekme tika novērota jau Babilonijā un Romas impērijā [88]. Mūsdienās pierādīts, ka kūdrai piemīt nozīmīgas antivīrusu, pretiekaisuma, hormonālo sistēmu stimulējošas, profibrinolītiskas un smago metālu saistīšanas spējas. Humusvielas var mainīt dažādu enzīmu, sevišksi ādā esošu enzīmu aktivitāti. Šis ir iemesls relatīvi plašai humusvielu izmantošanai vannas sāḷu un ādas masku gatavošanā. Kombinācijā ar dažādiem konservantiem tās tiek izmantotas dažādu slimību ārstēšanai, tām piemīt potenciāls cīņai ar vēzi.

Detalizēta humusvielu pretvīrusu aktivitātes izpēte sākusies pēc veiksmīgas cīnas ar mutes un nagu sērgu, izmantojot kūdras putekl̦us saturošus pakaišus. Jau pirmie pētījumi laboratorijas apstākḷos pierādīja, ka humīnskābes ir efektīvas pret coxsackie $A$ 9, influenza $A$ un herpes simplekss vīrusu. Citi pētījumi apstiprināja humusvielu spēju nomākt AIDS izraisītājus, cilvēka imūndeficīta vīrusa 1. un 2. tipu (HIV-1, HIV-2), citomegalovīrusu un govju baku vīrusu. Visbiežāk humīnskābju nomācošais efekts ietekmē vīrusa dalīšanās 
sākuma stadijas un vīrusa adsorbciju - traucē viriona piestiprināšanos šūnai [89].

Pierādīts, ka humusvielu ķīmiskās un bioksīmiskās īpašības var tikt izmantotas medicīnā [66, 90]. Atbrīvojot dažādus radikāļus, tās spēj cīnīties ar iekaisumiem un paātrināt brūču dzī̌sanu, tāpēc var tikt izmantotas terapijā pret infekcijas slimībām. Tāpat zināms, ka humusvielas saista trombīnu, kas izraisa trombozi, veicinot asins pieplūdi un līdz ar to arī brūču dzīšanu.

Izmantojot dažādas kompreses, humusvielu pretiekaisuma iedarbība jau ilglaicīgi ir izmantota gan cilvēku ārstēšanā, gan veterinārmedicīnā. Ar kūdras aplikumu cilvēkiem ir sekmīgi ārstēts reimatiskais artrīts, hroniski un subhroniski ǵenitāliju iekaisumi, sastopama informācija arī par sekmīgu parodontozes, dermatīta, ekzēmas, apdegumu, izgulējumu un iekaisušu brūču ārstēšanu [91]. Veterinārmedicīnā kūdras terapija ir veiksmīgi izmantota pietūkumu, artrītu, kontūziju, akūta un hroniska gastrīta ārstēšanā.

Tikai jaunākie pētījumi par humusvielu pretiekaisuma iedarbību dod ticamus izskaidrojumus par iedarbību bioķīmiskā līmenī - humīnskābes stimulē enzīma sintēzi, kas savukārt katalizē pretiekaisuma mediatoru sintēzi [89].

Kopš Ašheims un Holvegs [92] kūdras bitumena frakcijā atklāja estrogēnas vielas, notikuši daudzi mēg̣inājumi noteikt to ķīmisko sastāvu [91]. Humusvielu estrogēnā aktivitāte ir pētīta kastrētām pelēm. Rezultāti parādīja ievērojamu estrogēno aktivitāti Allena-Doisija testā (Allen-Doisy Test) aptuveni 5000 reižu augstāku nekā gaidīts [89]. Šie rezultāti norāda, ka tieši humusvielas nosaka kūdras estrogēno aktivitāti.

Humusvielām piemīt izteikta profibrolītiskā aktivitāte olvadu iekaisuma gadījumos. Pēc ķirurǵiskas iejaukšanās sterilizācijas nolūkos, kā arī lai novērstu olvadu sekundāru salipšanu un nosprostošanos, izmanto kūdras terapiju. Pēc terapijas fibrīni (olbaltumvielas, kas izraisa asins sarecēšanu) degradējas šķīstošos fibrīnu degradācijas produktos, tādējādi novēršot asins sarecējumu veidošanos un veicinot brūces sadzī̌̌anu.

Eksperimenti ar žurkām ir pierādījuši, ka kūdras ekstrakta vannām pēc ķirurğiskas iejaukšanās ir tieša brūču sadzī̌sanu veicinoša ietekme. Tas būtu izskaidrojams ar paātrinātu fibrīnu degradāciju humusvielu ietekmē. Šajā sakarā humusvielas varētu lietot trombu likvidācijā [89].

Ir pieejams liels daudzums informācijas par dabiskas izcelsmes humīnskābju spēju saistīt smagos metālus [89]. Ipaša nozīme ir faktam, ka šai sakarā atkarībā no uznemšanas veida tiek mainītas metālu jonu toksikoloǵiskās īpašības. Uzṇemot šos metālus orāli, to toksiskums samazinās, saistoties ar humusvielām, bet pieaug, uzņemot humusvielu metālu savienojumus parenterāli. Arī veterinārijā ir nozīmīga humusvielu spēja samazināt smago metālu intoksikāciju. Ridvans un Rohus [93, 94] novēroja, ka jau neliela humusvielu koncentrācija $(0,1 \%)$ pārtikā bija pietiekama, lai ievērojami samazinātu svina un kadmija asimilāciju žurkām [98].

Nesenā pētījumā pierādīts, ka humusvielas var inducēt apoptozi cilvēka endoteliālajās šūnās. Izmantojot visai augstas koncentrācijas (50-200 mg/L), pierādīta to ietekme uz šūnu dalī̌sanos, tās var sekmēt hromatīna kondensāciju un DNS fragmentāciju. Aǵenti, kas veic humusvielu agregāciju (vielas, kas veido hellātus ar Ca, vitamīnu E) var nomākt humusvielu inducēto apoptozi. Līdz ar to uzskatāms, ka humusvielas var būt būtisks faktors, kas lielos to uzņemšanas daudzumos var veicināt „melnās kājas slimību” (Blackfoot disease) [95].

Humusvielu arsēna komplekss ietekmē adenozina trifosfāta (ATF) asimilāciju sarkanajās asins šūnās (eritrocītos), bet augstās to koncentrācijās var izraisīt lipīdu peroksīdu veidošanos, līdz ar to sekmē stresa attīstību limfocītos [95].

Humusvielas tiek piedāvātas izmantot zivju audzēšanā. Šteinbergs [62] secinājis, ka lielākā daļa līdz šim izmantoto ūdens attīrīšanas piedevu, kuras piejauc ūdenim, lai kavētu kaitīgu aļǵ un dažādu parazịtu attīstību, zivīm izraisa toksiskus, kancerogēnus un teratogēnus efektus, tādējādi saīsinās to dzīvošanas ilgums. Savukārt humusvielu lietošana ne tikai uztur ūdens tīrību, bet arī palielina zivju, to ikru un kāpuru dz̄ivotspēju, samazina dažādu infekciju iespēju, kā arī veic kait̄̄gu metālu un ksenobiotiķu imobilizāciju. Galvenā problēma ir tā, ka humusvielas, kas iegūtas no vieniem un tiem pašiem avotiem un vienādām metodēm, ir ar lielu variabilitāti, bez tam daudzās valstīs humusvielas nav atḷauts izmantot terapijā [62].

\section{LITERATŪRAS SARAKSTS}

[1] Ellenberg, H. Vegetation ecology of Central Europe. Cambridge: Cambridge University Press, 1988. 756 p.

[2] Brown, P. A., Gill, S. A., Allen, S. J. Metal removal from wastewater using peat. Water research, 2000, vol. 34, p. 3907-3916. http://dx.doi.org/10.1016/S0043-1354(00)00152-4

[3] Pjavčenko, N. I. Kūdras purvi,to dabiskā un saimnieciskā nozīme. Maskava: Zinātne, 1985. 140 lpp. (Пьявченко, Н. И. Торфяные болота, их природное и хозяйственное значение. Москва: Наука, 1985. 140 c.)

[4] Brakšs, N. Purvi un kūdra. Rīga: LPSR ZA izdevniecība, 1961. 90 lpp.

[5] Montanarella, L., Jones, R. J. A., Hiederer, R. The distribution of peatland in Europe. In: Mires and Peat. University of Latvia Press, Riga et al., 2006, p. 56-70

[6] Overbeck, F. Botanisch - geologisch Moorkunde. Neumūnster: Karl Wacholtz Verlag, 1975. $719 \mathrm{~s}$.

[7] Borgmark, A. Holocene climate variability and periodicities in south central Sweden, as interpreted from humification analysis. The Holocene, 2005, vol. 15, p. 387-395. http://dx.doi.org/10.1191/0959683605hl816rp

[8] Vassander, H. Peatlands in Finland. Finland: Finnish peatland society, 1996. 168 p.

[9] Clymo, R. S. Peat. In: Mires: Swamp, Bog, Fen and Moor, Ecosystems of the World. Elsevier Scientific Publ., New York et al., 1986, p. 159 224.

[10] Strazdina, E. Dż̄̄ība purvā. Rīga: Latvijas Dabas Fonds, 1997. 16 lpp.

[11] Muller, S. D., Richard, P. J. H., Laureche, A. C. Holocene development of a peatland (southern Quebec): a spatio - temporal reconstruction based on pachymetry, sedimentology, microfossils and macrofossils. The Holocene, 2003, vol. 13, p. 649-664. http://dx.doi.org/10.1191/0959683603hl642rp

[12] Orru, M. Global Peat Resource. Peat Resources of Estonia. Finland: International Peat Society, 1996, p. 65-68.

[13] Nomals, P. Vidzemes un Latgales purvu apskats. Rīga: Zemes bagātību pētǐšanas institūts, 1943. 486 lpp.

[14] Jauhiainen, S., Pitkanen, A., Vasander, H. Holocene development of two boreal mires and ecological effects of drainage and restoration. Chemostratigraphy and vegetation of two boreal mires during the holocene. 2003, p. 31-33.

[15] Nicenko, A. A. İsais kurss purvu zinātnē. Maskava: Zinātne, 1967. 68. lpp. (Ниценко, А. А. Краткий курс болотоведения. Москва: Наука, 1967. 68 c.)

[16] Foster, D. R., Fritz S. C. Mire development, pool formation and landscape processes on patterned fens in Dalarna, central Sweden. Journal of Ecology, 1987, vol. 75, p. 409-437. http://dx.doi.org/10.2307/2260426 
[17] Galeniece, M. Dažu Kurzemes purvu stratigrāfija un genēze. In: Latvijas PSR vegetācija. 3. sēj., Rīga, LPSR ZA izdevniecība, 1960, 2141. lpp.

[18] Tjuremnovs, S. N. Kūdras nogulumi un to izpēte. Maskava: Nedra, 1976. 487 lpp. (Тюремнов С. Н. Торфяные месторождения и их разведка. Москва: Недра, 1976. 487 с.)

[19] Koppisch, D. Torfbildung. In: Landschaftsökologische Moorkunde. Schweizerbart, Stuttgart et al., 2001, p. 8-16.

[20] Ball, P. H2O. A biography of water. Orion, London, 2000. 145 p.

[21] Moore, P. D. The origin of blanket mir e, revisited. In: Climate change and human impact on the landscape. Chapman \& Hall, London et al., 1993, p. 217-224.

[22] Ivanov, K. E. Water movement in mirelands. Translated by Thomson, A. and Ingram, H.A.P. from Ivanov, K.E. 1975. Vodoobmen v bolotnykn landshaftakh. Academic Press, London, 1981. 278 p.

[23] Šnore, A. Kūdra Latvijā. Rịga: Latvijas Kūdras ražotāju asociācija, 2004. 64 lpp.

[24] Latvijas PSR kūdras fonds. 1961.

[25] Fischer, J. Versuch einer Naturgeschichte von Livland. Zweite vermehrte und verbesserte Auflage Kõnigsberg, 1791. $294 \mathrm{~s}$.

[26] Grosvalds, I., Alksnis, U. Docents Nikolajs Brakšs - dzīve un personība. LU raksti. zinātnu vēsture un muzejniecība, 2007, vol. 704, p. 137-147.

[27] Lācis, A. Rietumlatvijas kūdras resursi. Rīga: Valsts ǵeologijas dienests, 1996. 43 lpp.

[28] Finkelšteins, M. I., Karpuhins, V. I., Kutevs, V. A., Metalkins, V. N. Pazemes radiolokācija. Maskava: Radio un sakari, 1994. 215 lpp.(Финкельштейн, М. И., Карпухин, В. И., Кутев, В. А., Метелкин, В. Н. Подповерхностная радиолокация. Москва: Радио и связь, 1994,215 с. )

[29] Schilstra, A. J. How sustainable is the use of peat for commercial energy production. Journal of Ecological Economics, 2001, vol. 39, p. 285-293. http://dx.doi.org/10.1016/S0921-8009(01)00216-6

[30] Gnatowski, T., Szatylowicz, J., Brandyk, T., Kechavarzi, C. Hydraulic properties of peat in Poland. Geoderma, 2010, vol. 154, p. 188-195. http://dx.doi.org/10.1016/j.geoderma.2009.02.021

[31] Black, W. A. P., Cornhill, W. J., Woodwaed, F. N. A preliminary investigation on the chemical composition of sphagnum moss and peat. Journal of Applied Chemistry, 1955, vol. 5, p. 484-492. http://dx.doi.org/10.1002/jctb.5010050907

[32] Romanovs, V. V. Purvi un to īpašības. L̦eņingrada: Hidrometeoizdat, 1953. 296 lpp. (Романов, В. В. Болота и их свойства. Ленинград: Гидрометеоиздат, 1953. 296 с.)

[33] Colin, I. Vegetation responsis to past climatic variation. Vegetation, 1985, vol. 67, p. 131-141. http://dx.doi.org/10.1007/BF00037363

[34] Kḷaviņš, M. Immobilization of humic substances. Latvijas ķīmijas žurnāls, 1993, vol. 1, p. 96-102.

[35] Klavins, M., Sire, J., Purmalis, O., Melecis, V. Approaches to estimating humification for peat. In: Mires and Peat, University of Latvia Press, Riga et al., 2008, p. 1-17.

[36] Bozkurt, S., Lucisano, M., Moreno, L., Neretnieks, I. Peat as potencial analogue for the long - term evolution in landfills. Earth Science Reviews, 2001, vol. 53, p. 95-147. http://dx.doi.org/10.1016/S0012-8252(00)00036-2

[37] Orru, M., Orru, H. Sustainable use of Estonian peat reserves and environmental challenges. Estonian Journal of Earth Sciences, 2008, vol. 57, N. 2, p. 87-93. http://dx.doi.org/10.3176/earth.2008.2.04

[38] Joosten, H., Clarke, D. Wise Use of Mires and Peatlands. International Mire Conservation Group: International Peat Society, 2002. 304 p.

[39] The history of peat in Quebec and around the world [tiešsaiste]. Quebec peat moss producers association. [skatīts 17.05.2013.]. Pieejams: http://www.tourbehorticole.com/en/peat/history.php

[40] All about Scotch Whisky [tiešsaiste]. The website of beverage testing $\begin{array}{llll}\text { institute. [skatīts } & 17.05 .2013 .] & \text { Pieejams: }\end{array}$ http://www.tastings.com/spirits/scotch.html

[41] Sustainable management of peatland forests in southeast Asia [tiešsaiste]. ASEAN Peatland Forests Project. [skatīts 17.05.2013.]. Pieejams: http://www.peat-portal.net/index.cfm?\&menuid $=44$

[42] History and uses of peat [tiešsaiste]. Environment and heritage service. [skatīts 17.05.2013.]. Pieejams: http://www.creativeinput. net/work/websites/peatlands/history/int_uses.html

[43] Ewald, F. Re: The current Importance of peat textiles. In: Anthromedlibrary [tiešsaiste]. [skatīts 18.05.2013.]. Pieejams: http://www.anthromed.org/Article.aspx?artpk=252
[44] Ireland peat bogs [tiešsaiste]. Travel through the Ireland story. [skatits 21.05.2013]. Pieejams: http://www. wesleyjohnston. com/users/ireland/ geography/bogs.html

[45] What does peat change in an aquarium [tiešsaiste]. Aqua-fish.net [skatīts 20.05.2013.]. Pieejams: http://www.aqua-fish.net/show.php?h= aquariumpeat

[46] Ļistvans, I. Kūdras fizioḳīmiskās īpašības. Ķīmiskā un termiskā pārstrāde. Fosilā kurināmā k̦īmija, 1996. 3. sēj. 3-23. lpp. (Лиштван, И. Физико-химические свойства торфа. Химическая и термическая его переработка. Химия Твёрдого Топлива, 1996, Топ. 3; 3-23. с.)

[47] Klavins, M., Porshnov, D. Development of a new peat-based oil sorbent using peat pyrolysis, Environmental Technology, 2013, http://dx.doi.org/10.1080/09593330.2012.758668

[48] Korjakins, A., Toropovs, N., Kara, P., Upeniece, L. Application of Peat, Wood Processing and Agricultural Industry By-products in Producing the Insulating Building Materials. Journal of Sustainable Architecture and Civil Engineering, 2013, vol. 1, N. 2, p. 1-7. http://dx.doi.org/10.5755/j01.sace.1.2.2884

[49] Aikaite, J., Gyliene, O., Salkauskas, M. Sorption of complexed and uncomplexed $\mathrm{Cu}(\mathrm{II}), \mathrm{Ni}(\mathrm{II})$ and $\mathrm{Zn}$ ions by peat. Chemija, 2001, vol. 12, p. $183-188$.

[50] Ringqvist L., Oborn I. Copper and Zinc Adsorption onto Poorly Humifed Sphagnum and Carex Peat. Water Research, 2002, vol. 36, p. 2233-2242. http://dx.doi.org/10.1016/S0043-1354(01)00431-6

[51] Qin, F., Wen, B., Shan, X. Q., et al. Mechanisms of competitive adsorption of $\mathrm{Pb}, \mathrm{Cu}$ and $\mathrm{Cd}$ on peat. Environmental Pollution, 2006, vol. 144, p. 669-680. http://dx.doi.org/10.1016/j.envpol.2005.12.036

[52] Trung, B., Dat, D. P., Le Cloirec, et al. Activation and characterization of U Minh peat (Vietnam) for vapor volatile organic compounds adsorption. Workshop of the French-Vietnamese project in water quality and treatment. Book of Proceedings, Hanoi: Vietnam, 2004.

[53] Ringqvist, L., Oborn, I. Copper and zinc adsorption onto poorly humifed Sphagnum and Carex peat. Water Research, 2002, vol. 36, p. 2233-2242. http://dx.doi.org/10.1016/S0043-1354(01)00431-6

[54] Fiol, N., Villaescusa, I., Martinez, M., et al. Biosorption of Cr (VI) using low cost sorbents. Environmental Chemistry Letters, 2003, vol. 1, p. 135-139. http://dx.doi.org/10.1007/s10311-003-0027-6

[55] Xiong, J. B., Mahmood Q. Adsorptive Removal of Phosphate from Aqueous Media by Peat. Desalination, 2010, vol. 259, p. 59-64. http://dx.doi.org/10.1016/j.desal.2010.04.035

[56] Rasmussen, G., Fremmersvik, G., Olsen, R .A. Treatment of creosotecontaminated groundwater in a peat/sand permeable barrier - a column study. Journal of Hazardous Materials, 2002, vol. 93, p. 285-306. http://dx.doi.org/10.1016/S0304-3894(02)00056-0

[57] Ringqvist, L., Holmgren A., Oborn, I. Poorly Humified Peat as an Adsorbent for Metals in Wastewater. Water Resources, 2002, vol. 36, p. 2394-2404.

[58] Thirunavukkarasu, O. S. Viraraghavan, T., Subramanian, K. S. Removal of arsenic in drinking water by iron oxide-coated sand and ferrihydrite -batch studies. Water Quality Research Journal, 2001, vol. 36 , N. 1 , p. $55-70$.

[59] Loukidou, M. X., Matis, K. A., Zouboulis, A. I., LiakopoulouKyriakidou, M. Removal of As (V) from wastewaters by chemically modified fungal biomass. Water Research, 2003, vol. 37, p. 4544-4552. http://dx.doi.org/10.1016/S0043-1354(03)00415-9

[60] Shermer, C. L., Maciorowski, K. G., Bailey, C. A., et al. Caecal metabolites and microbial populations in chickens consuming diets containing a mined humate compound. Journal of the Science of Food and Agriculture, 1998, vol. 77, p. 479-486. http://dx.doi.org/10.1002/(SICI)1097-0010(199808)77:4<479::AIDJSFA607>3.0.CO;2-L

[61] Stevenson, F. J. Humus Chemistry - Genesis, Composition, Reactions. Newyork.: John Wiley and Sons, 1982. $107 \mathrm{p}$.

[62] Steinberg, E. W. Ecology of humic substances ion freshwaters. Verlag Berlin Heidelberg: Springer, 2003. 440 p. http://dx.doi.org/10.1007/9783-662-06815-1

[63] Hessen, D. O., Tranvik, L. Aquatic humic substances: Ecology and Biogeochemistry. Ecological Series, 1988, vol. 133, 346 p.

[64] Aiken, G. R. Isolation and concentration techniques for aquatic humic substances. In: Humic substances in soil, sediments and water. Wiley, Newyork et al., 1985. p. 527-559.

[65] Kḷavin̄š, M. Aquatic humic substances. Riga: University of Latvia Press, 1998, $234 \mathrm{p}$.

[66] Ziechmann, W. Humic substances. Mannheim: BI Wissenschafts Verlag, 1944, $300 \mathrm{p}$. 
[67] Chen, Y., Aviad, T. Effects of humic substances growth. Humic substances in soil and crop sciences. Soil Science of America, 1990, p. 161-186.

[68] Malcolm, R. L. Geochemistry of stream fulvic and humic substances. In: Humic subsbtances in soil, sediments and water. Wiley, Newyork et al., 1985, p. 181-210.

[69] Brinkmann, T., Horsch, P., Sartorius, D., Frimmel, F. Photoformation of low-molecular-weight organic acids from brown water dissolved organic matter Environmental Science and Technology, 2003, vol. 37, p. 4190-4196. http://dx.doi.org/10.1021/es0263339

[70] Buffle, J. Complexation reactions in aquatic systems. Chichester: Ellis Horwood. 1988, 300 p.

[71] Orlovs, D. S., Sadovnnikova, L. K., Lozanobskaja, I. N. Ekologija un biosfêras aizsardzība kīmiskā piesārnojuma gadījumā. Maskava: Augstskola, 2002, 334. lpp. (Орлов, Д. С., Садовникова, Л. К., Лозановская, И. Н. Экология и охрана биосферы при химическом загрязении. Москва: Высшая школа. 2002, 334. с.)

[72] Kononova, M. M. Soil organic matter, Oxford: Pergamon Press, 1966, $200 \mathrm{p}$.

[73] Schnitzer, M. Humic substances: chemistry and reactions. In: Soil organic matter. Elsevier, Amsterdam et al., 1978, p. 1-64.

[74] Rice, J. A., MacCarthy, P. Isolation of humin by liquid-liquid partitioning. Science of the Total Environment, 1989, vol. 81/82, p. 6169. http://dx.doi.org/10.1016/0048-9697(89)90111-3

[75] Giesy, P. J., Geiger, A. R., Kevern, R. N., Alberts, J. J. $\mathrm{UO}_{2}{ }^{2+}-$ humate interactions in soft, acid, humate - rich waters. Journal of Environmental Radioactivity, 1986, vol. 4, p. 39-64. http://dx.doi.org/10.1016/0265-931X(86)90020-2

[76] Wallsclager, D., Desai, M. V. M., Wilken, R. D. The role of humic substances in the aqueous mobilization of mercury from contaminated floodplain soils. Water, air and soil pollution, 1996, vol. 90, p. 507-520. http://dx.doi.org/10.1007/BF00282665

[77] Weng, L., Fest, E. P. M., Fillius, J.,et al. Transport of humic and fulvic acids in relation to metal mobility in a copper - contaminated acid sandy soil. Environmental Science Technology, 2002, vol. 36, p. 1699-1704. http://dx.doi.org/10.1021/es010283a

[78] Markich, J. S., Brown, L. P., Jeffree, A. R. The use of geochemical specification modelling to predict the impact of uranium to freshwater biota. Radiochimica Acta, 1996, vol. 74, p. 321-326.

[79] Penttinen, S., Kostamo, A., Kukkonen, J. Combined effects of dissolved organic material and water hardness on toxicity of cadmium to Daphnia magna. Environmental toxicology and chemistry, 1988, vol. 17 p. 2498-2503.

[80] Porta, A. A., Ronco, E. A. Cu (II) acute toxicity to the rotifer Brachionus calyciforus, as affected by fulvic acids of freshwater origin. Environmental pollution, 1993, vol. 82, p. 263-267. http://dx.doi.org/10.1016/0269-7491(93)90128-B

[81] Gauthler, D. T., Seltz, W. R., Grant, L. C. Effects of structural and compositional variations of dissolved humic materilas on pyrene $\mathrm{K}_{\mathrm{oc}}$ values. Environmental Science and Technology, 1987, vol. 21, p. 243248. http://dx.doi.org/10.1021/es00157a003

[82] Murphy, M. E., Zachara, M. J., Smith, C. S., et al. Interaction of hydrophobic organic compounds with mineral - bound humic substances. Environmental Science and Technology, 1994, vol. 28, p. 1291-1299. http://dx.doi.org/10.1021/es00056a017

[83] Zimina, V. A., Ammosova, M. Y. Adsorption of simazine by humic acids of different origin. Eurasian Soil Science, 1995, vol. 8, p. 952-955.

[84] Chin, Y. P., Aiken, G. R. Danielsen, M. K. Binding of pyrene to aquatic and commercial humic substances: the role of molecular weight and aromacity. Environmental Science Technology, 1997, vol. 31, p. 1630-1635. http://dx.doi.org/10.1021/es960404k

[85] Saint-Fort, R., Visser, S. A. Study of the interactions between atrazine, diazinon and lindane with humic acids of various molecular weights. Journal of Environmental Science and Health, 1988, vol. 23, N. 6, p. 613-624.

[86] Industry substances from peat [tiešsaiste]. Humapon.cn. [skatīts 10.03.2012.]. Pieejams: http://www.humapon.cn/Industry.html

[87] Twardowska, I., Kyziol, J., Goldrath, T., Avnimelech, Y. Adsorption of zinc peat from peatlands of Poland and Israel. In: Journal of geochemical exploration, 1999, vol. 66, p. 387 - 405 . http://dx.doi.org/10.1016/S0375-6742(99)00034-5

[88] Priegnitz, H. Wasserkund und Badelust. Leipzig: Koehler \& Amelang, $1986,150 \mathrm{p}$.
[89] Klöcking, R. Humic substances as potential therapeutics. Humic substances in the global environment and implications on human health, 1994, p. 1245-1257.

[90] Flaig, W. Aspects of the biochemistry of the healing effects of the humic substancesfrom peat. Humic substances, peats and sludges: health and environmental aspects. 1997, p. 346-356.

[91] Zsunshuj, V., Tschen, P., Njanzy, L., Sjaona, T. Untersuchungen des antiphlogistischen Effektes von Huminsäuren. In: Torf in der Medizin. Sympozium der Komission VI der IMTG. Bad Elster, 1981, p. 358-362.

[92] Aschheim, S., Hohlweg, W. Uber das Vorkommen ostrogener Wirkstoffe in Bitumen. Deutsches Medizinisches Wochenschrift, 1933, vol. 59, N. 1, p. 12-14. http://dx.doi.org/10.1055/s-0028-1131410

[93] Ridwan, F. N. J. Untershutzungen zum Einfluss von Huminsauren auf die Blei- und Cadmium- Absorbtion bei Ratten. Gottingen: Universitat Gottingen, 1977. $90 \mathrm{p}$.

[94] Rochus, W.Z. Physiother. Physiother, 1983, vol. 35, p. 23-30.

[95] Hseu, Y., Huang, H. W., Wang, S. Y., et al. Humic acid induces apoptosis in human endothelial cells. In: Toxicology and applied Pharmacology, 2002, vol. $\quad 182, \quad$ p. 34-43. http://dx.doi.org/10.1006/taap.2002.9429

[96] Painter, J.T. Carbohydrate polymers in food preservation: an integrated view of the Maillard reaction with special reference to discoveries of preserved foods in Sphagnum - dominated peat bogs. Carbohydrate polymers, 1998, vol. 36, p. 335-347. http://dx.doi.org/10.1016/S0144$\underline{8617(97) 00258-0}$

Janis Krumins. Mg.sc. geol. PhD student in Environmental Science at the University of Latvia, Faculty of Geography and Earth Sciences. Bachelor degree in geology earned at University of Latvia in 2009; Master degree in geology earned at University of Latvia in 2011. The major field of study: applied geology, quaternary geology and environmental science.

Address: University of Latvia, Raina bulv. 19, LV-1586, Riga, Latvia.

E-mail: krumins.janis@lu.lv

Artis Robalds, Mg. sc. env., PhD. student at the University of Latvia, Faculty of Geography and Earth Sciences, Department of Environmental Sciences. Research interests are related to constructed wetlands, peat and other biosorbents in the treatment of polluted waters.

Address: University of Latvia, Raina bulv. 19, LV-1586, Riga, Latvia.

E-mail: artis.robalds@lu.lv

Oskars Purmalis (PhD student) received his bachelor's degree in environmental sciences from University of Latvia (Faculty of Geography and Earth sciences) in 2006 and master degree in 2008. Since the 2008 he is $\mathrm{PhD}$ Student and reseacher at the laboratory of environmental monitoring (Department of Environmental Sciences, Faculty of Geography and Earth Sciences, University of Latvia). The major interests are related to environmental chemistry, environmental proceses and nature conservation. $\mathrm{He}$ is a member of the International Humic Substances Society since 2006.

Address: Raina bulv. 19, LV-1050, Riga, Latvia.

E-mail: oskars.purmalis@lu.lv

Linda Ansone, Mg.sc.chem. L. Ansone (PhD student) received her B.sc. and Mg.sc. in Chemistry from University of Latvia (Faculty of Chemistry) in 2009 and 2011. Since the year 2008 she is a laborant at Department of Environmental Science, Faculty of Geography and Earth Science. Since the year 2013 she is a chair of Soil science laboratory at University of Latvia, Faculty of Geography and Earth Sciences. She is a member of International Humic Substance Society (IHSS).

Address: University of Latvia, Raina bulv. 19, LV-1586, Riga, Latvia. E-mail: linda_ansone@inbox.lv

Dmitry Porshnov received his bachelor's degree in environmental sciences from University of Latvia (Faculty of Geography and Earth Sciences) in 2011. Since the 2012 he is a researcher in the Department of Environmental Sciences, Faculty of Geography and Earth Sciences, University of Latvia. His major fields of study are: managment of chemical environmental pollution and sustainable use of Earth resources. He is a member of the Latvian Association for Quarternary Research since 2011.

Address: Raina bulv. 19, LV-1050, Riga, Latvia.

E-mail: dmitrijs.porsnovs@lu.lv

Maris Klavins, Dr. hab. chem., Professor at the University of Latvia, Faculty of Geography and Earth Sciences, Department of Environmental Sciences. M. Klavins obtained his scientific degree in chemistry of 
biologically active compounds at the Moscow State University in 1986 but a habilitation degree at the University of Latvia in 1994. He is a member of the Academy of Sciences of Latvia, coordinator of International Humic Substances Research Society (IHSS). Research interests are related to studies of natural organic matter, wetlands and bogs and environmental pollution problems.

Address: University of Latvia, Raina bulv. 19, LV-1586, Riga, Latvia. E-mail: maris.klavins@lu.lv
Valdis Seglinšs. Dr. geol., Professor at the University of Latvia, Faculty of Geography and Earth Sciences, Department of Applied Geology. Education: Leningrad Mining Institute (St. Petersburg Mining University), 1981. Cand. Sc. geol. - mineralogy. 1987. Dr. geol., University of Latvia, 1992. The major interests: applied geology, quaternary geology, geophysics, economic geology.

Address: University of Latvia, Raina bulv. 19, LV-1586, Riga, Latvia.

E.-mail: valdis.seglins@lu.lv

\section{Janis Krumins, Artis Robalds, Oskars Purmalis, Linda Ansone, Dmitrijs Porsnovs, Maris Klavins, Valdis Seglins. Peat Resources and} Application Areas

In Latvia and elsewhere in the world, peat is used in much smaller amounts than it would be economically justified even without compromising the natural values. This article deals with peat resources and their application areas. In our study, peat is viewed as a valuable natural resource and base material for various substances such as drugs, food additives, sorbents and others (even as material for textiles). In this article, the most typical application areas of peat and of its components are characterized and described. Even though peat is commonly used as raw material in heating or power generation, its applications go far beyond this area. For instance, raised bog peat can be used for mummification purposes - it was widely used in religious sacrifice rituals in primitive cultures. The fibre of peat can be used as yarn, and characteristics of peat yarn are even better than wool characteristics; it has natural abilities to protect human skin from UV radiation. In this manner, peat is also used as building material. One of the most significant components of peat mass is a humic substance, chemical properties of which allow using peat in medicine and food industry. During this study, the authors have concluded that peat is priceless natural treasure with a wide area of applications and we can significantly increase the yield of peat without any threat to nature or natural diversity; actually, it is possible to find application for every single piece of peat material.

Янис Круминьш, Артис Робальдс, Оскарс Пурмалис, Линда Ансоне, Дмитрий Поршнёв, Марис Клявиньш, Валдис Сеглиньш. Торфяные ресурсы и возможности их использования.

В Латвии, также как и во всём мире, торфяные ресурсы используются в значительно меньших количествах, чем это возможно, как с точки зрения экономики, так и экологии. Этот обзор посвящён торфяным ресурсам и возможностям их использования. Торф здесь рассмотрен, как ценный природный ресурс и исходный материал для различных продуктов: лекарств, пищевых добавок, препаратов для очистки загрязнённых сред, текстильных материалов и т.д. Охарактеризованы и описаны главные пути использования торфа и его составляющих. Возможности использования торфа ни в коем случае не ограничены традиционным путём его применения: энергетикой. Как один из примеров применения, совершенно не известных широкой публике, можно упомянуть использование сфагновых торфов примитивными культурами для мумификации тел. Торфяное волокно может быть использовано для производства ткани, характеристики которой превышают соответствующие свойства шерстяной ткани по многим параметрам: например возможности защиты кожи от УВ излучения. Характеризованы возможности использования одной из важнейших составляющих торфа: гуминовых веществ, химические свойства которых позволяют использовать торф в медицине и пищевой промышленности. В результате обзора источников авторы приходят к выводу, что торф является бесценным природным богатством с очень широкими возможностями применения, который можно добывать и использовать в больших количествах, чем в данный момент, без существенного вреда для среды и естественного разнообразия. Более того, использование торфа может быть комплексным и совершенно безотходным. 